\title{
Role of Protein Kinase C in Bipolar Disorder: A Review of the Current Literature
}

\author{
Ashwini Saxena $^{a}$ Giselli Scaini $^{a}$ Daniela V. Bavaresco $^{b}$ Camila Leite $^{b}$ \\ Samira S. Valvassoriab ${ }^{b}$ André F. Carvalho ${ }^{c}$ João Quevedo ${ }^{a}$ b, d, e \\ ${ }^{a}$ Translational Psychiatry Program, Department of Psychiatry and Behavioral Sciences, McGovern Medical School,

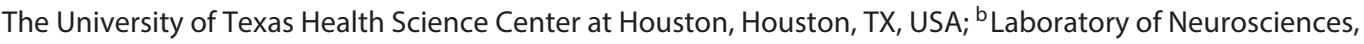 \\ Graduate Program in Health Sciences, Health Sciences Unit, University of Southern Santa Catarina, Criciúma, and \\ 'Translational Psychiatry Research Group, Faculty of Medicine, Federal University of Ceara, Fortaleza, Brazil; ' ${ }^{\mathrm{d}}$ Center \\ of Excellence on Mood Disorders, Department of Psychiatry and Behavioral Sciences, McGovern Medical School, \\ The University of Texas Health Science Center at Houston, and eNeuroscience Graduate Program, The University of \\ Texas Graduate School of Biomedical Sciences at Houston, Houston, TX, USA
}

\section{Keywords}

Mood disorder - Bipolar disorder - Protein kinase $C$. Lithium · Valproic acid · Tamoxifen

\begin{abstract}
Bipolar disorder (BD) is a major health problem. It causes significant morbidity and imposes a burden on the society. Available treatments help a substantial proportion of patients but are not beneficial for an estimated $40-50 \%$. Thus, there is a great need to further our understanding the pathophysiology of BD to identify new therapeutic avenues. The preponderance of evidence pointed towards a role of protein kinase $C(P K C)$ in $B D$. We reviewed the literature pertinent to the role of PKC in BD. We present recent advances from preclinical and clinical studies that further support the role of PKC. Moreover, we discuss the role of PKC on synaptogenesis and neuroplasticity in the context of BD. The recent development of animal models of BD, such as stimulant-treated and paradoxical sleep deprivation, and the ability to intervene pharmacologically provide further insights
\end{abstract}

\section{KARGER}

(C) 2017 S. Karger AG, Basel into the involvement of PKC in BD. In addition, the effect of PKC inhibitors, such as tamoxifen, in the resolution of manic symptoms in patients with BD further points in that direction. Furthermore, a wide variety of growth factors influence neurotransmission through several molecular pathways that involve downstream effects of PKC. Our current understanding identifies the PKC pathway as a potential therapeutic avenue for BD.

(c) 2017 S. Karger AG, Basel

\section{Introduction}

Bipolar disorder (BD) is a chronic and life-threatening disorder, and has been identified as one of the leading causes of disability worldwide [1]. BD is classically characterized by recurrent fluctuation between distinct periods of both positive (mania) and negative (depression) extremes of mood state. Additional features frequently associated with BD are impairment in emotion perception, affect regulation, attention, and executive function-

João Quevedo, $\mathrm{MD}, \mathrm{PhD}$

Department of Psychiatry and Behavioral Sciences

The University of Texas Medical School at Houston

1941 East Road, Ste. 3140, Houston, TX 77054 (USA)

E-Mail Joao.L.DeQuevedo@ uth.tmc.edu 
ing [2]. These impairments also correlate with structural and functional abnormalities in frontolimbic brain regions, such as prefrontal cortex (PFC), hippocampus, and amygdala, that regulate emotion, memory, and motivated behavior [3]. Despite its heavy toll on human lives, the molecular mechanisms underlying the pathogenesis of $\mathrm{BD}$ remain elusive.

Initial insights into the pathophysiology BD were gained in 1980s after the serendipitous discovery of lithium [4] and valproic acid [5] as effective mood stabilizers. In the past 10 years, several animal models of mania have been developed to mimic human $\mathrm{BD}$ [6]. The manic phenotype is usually induced in animal models by pharmacological (amphetamine [AMPH] and ouabain), environmental (paradoxical sleep deprivation [PSD]), and genetic(blackSwiss mice) interventions [6]. Theseinterventions induce behavioral changes that are analogous to manic symptoms, such as hyperlocomotion [7], insomnia, risktaking behavior [8], and increased appetitive $50-\mathrm{kHz}$ ultrasonic vocalizations (USV; a marker for euphoric mood and pressured speech) [9]. These models are tested for their face (animals mimicking manic symptoms), construct (correlation of similar pathophysiological alteration at molecular level), and predictive (amelioration of symptoms by currently accepted treatments of mania) validity to enhance our understanding of BD [10]. Our advances in neuroimaging techniques, such as in vivo magnetic resonance imaging, and novel genetic approach, such as convergent functional genomics, are providing us endophenotypic characteristics of BD [11]. After 3 decades of intensive preclinical and translational research, protein kinase $\mathrm{C}$ (PKC) has come to be recognized to play a central role in the pathophysiology of BD [12-14].

The protein kinase family of proteins is one of the largest superfamily of nearly 500 proteins that are evolutionarily conserved across 11 eukaryotic species and regulate various cellular events $[15,16]$. The PKC family includes 10 serine/threonine protein kinases that are encoded by 9 mammalian genes and reversibly phosphorylate serine, threonine, and tyrosine residues in their target proteins [15]. These 10 kinases are subdivided into 3 subfamilies based on their structure and their regulatory cofactors, namely classical or conventional PKC [CPKC: $\alpha, \beta_{\mathrm{I}}, \beta_{\mathrm{II}}$, and $\gamma$; regulated by phospholipids, $\mathrm{Ca}^{2+}$ ions, and diacylglycerol (DAG)], novel PKC (nPKC: $\varepsilon, \delta, \eta, \theta$, and $\mu$; regulated by phospholipid and DAG), and atypical PKC (aPKC: $\xi, \mathrm{M} \xi$, l, and $\lambda$; regulated by phospholipids but are independent of DAG and $\mathrm{Ca}^{2+}$ ions) [17]. All PKCs consist of a highly conserved C-terminal catalytic domain and a nonconserved $\mathrm{N}$-terminal regulatory domain [18].

Role of PKC in Bipolar Disorder
In the $\mathrm{CNS}, \mathrm{cPKC}$ subfamily enzymes, $\mathrm{PKC} \alpha,-\beta$, and $-\gamma$, are most abundantly expressed [19] and influence neuronal signaling by short-term (neurotransmitter release and ion fluxes), medium-term (receptor regulation), and long-term (cell proliferation, synaptic remodeling, and gene expression) mechanisms [20]. PKC isozymes are highly expressed in the frontolimbic structures, such as PFC, hippocampus, and amygdala, which are involved in mood regulation [21, 22]. PKC is inhibited by mood stabilizers such as lithium and valproic acid [14]. Additionally, PKC signaling is involved in the regulation of processes that are affected in $\mathrm{BD}$, such as neuronal excitability [23], neurotransmitter release [24, 25], glutamatergic neurotransmission [26], neuroplasticity [27], apoptotic pathway activation [28], mitochondrial dysfunction, and oxidative stress [29], and neuroinflammation [3032].

We searched PubMed database with key words "protein kinase $\mathrm{C}$ bipolar disorder" and "PKC bipolar disorder" and selected articles since 2008. Few earlier manuscripts are tabulated in the article to provide a historical context of recent observations. We reviewed a total of 26 studies ( 9 in vitro, 11 in vivo, and 6 clinical studies). We organized our narrative to address proposed pathophysiological mechanisms underlying BD, including: (1) PKC translocation and activity; (2) putative downstream molecular effects, and (3) gene candidates. The studies are indexed in Tables 1-4.

\section{PKC Translocation and Activity}

\section{Preclinical Studies}

The importance of hyperactive PKC signaling in $\mathrm{BD}$ was first appreciated when commonly used mood stabilizers, both lithium and valproic acid, were observed to inhibit PKC activity in vitro [33, 34] and in vivo [35-37]. Later, the levels of membrane-associated PKC were shown to decrease after exposure to lithium and valproic acid, in vitro [38] and in vivo [39, 40]. These observations were corroborated in humans when chronic treatment with lithium decreased PKC signaling in euthymic patients with BD [41]. One of the mechanisms underlying this mitigation of PKC hyperactivity by lithium and valproic acid is the inhibition of its translocation from cytosol to cell membrane. PKC is known to translocate to cell membrane when stimulated by phorbol esters (phorbol 12-myristate 13 -acetate [PMA]), serotonin (5HT), $\mathrm{K}^{+}$ ions [42], and DAG analogs in vitro [43] and ex vivo [34]. It has been shown that platelets from patients in acute

Mol Neuropsychiatry 2017;3:108-124 DOI: $10.1159 / 000480349$ 
Table 1. Summary of the in vitro studies

\begin{tabular}{|c|c|c|c|c|}
\hline $\begin{array}{l}\text { First author [Ref.], } \\
\text { year }\end{array}$ & Model & Design & Duration & Main findings \\
\hline Chen [38], 1994 & C6 glioma cell line & $\begin{array}{l}\text { Valproic acid exposure } \\
0.6 \mathrm{nM}\end{array}$ & $6-7$ days & $\begin{array}{l}\text { Decreased PKC alpha and epsilon (not delta or } \\
\text { zeta) in both membrane and cytosolic } \\
\text { compartment; increased cytosolic/membrane } \\
\text { ratio of PKC activity }\end{array}$ \\
\hline $\begin{array}{l}\text { Kirshenboim } \\
{[132], 2004}\end{array}$ & $\begin{array}{l}\text { HEK } 293 \text { and PC12 } \\
\text { cell line }\end{array}$ & $\begin{array}{l}\text { Lithium treatment } \\
0-20 \mathrm{mM}\end{array}$ & $0-6 \mathrm{~h}$ & $\begin{array}{l}\text { Lithium increased inhibition of GSK-3beta by } \\
\text { increasing phosphorylation of inhibitory site of } \\
\text { GSK-3beta (Ser 9) in HEK } 293 \text { and PC12 cells via } \\
\text { PI3-PKC signaling; lithium increased PKC alpha } \\
\text { activity twofold in both cell lines }\end{array}$ \\
\hline Kim [102], 2009 & $\begin{array}{l}\text { Cultured } \\
\text { hippocampal } \\
\text { neurons }\end{array}$ & $\begin{array}{l}\text { Lithium treatment } \\
5.0 \mathrm{mM}\end{array}$ & $4 \mathrm{~h}$ & $\begin{array}{l}\text { Lithium increased number of functional synapses } \\
\text { in cultured hippocampal neurons via action of } \\
\text { glutamate on postsynaptic receptors; no change } \\
\text { in PKC activity reported }\end{array}$ \\
\hline Ou [101], 2009 & $\begin{array}{l}\text { PC12 cell line and } \\
\text { human astrocytes }\end{array}$ & $\begin{array}{l}\text { Lithium treatment } \\
100 \mathrm{mM}\end{array}$ & $12 \mathrm{~h}$ & $\begin{array}{l}\text { Lithium elongates cilia in PC12 and human } \\
\text { astrocytes via cAMP signaling pathway }\end{array}$ \\
\hline $\begin{array}{l}\text { Rittiner [158], } \\
2014\end{array}$ & HEK 293 cell line & $\begin{array}{l}\text { Overexpressed mouse } \\
\text { DGKn in human embryonic } \\
\text { kidney } 293 \text { cells }\end{array}$ & - & $\begin{array}{l}\text { DGKeta reduces PKC activation and enhances } \\
\text { GPCR signaling }\end{array}$ \\
\hline
\end{tabular}

mania show enhanced 5HT-induced PKC translocation and membrane-bound $\mathrm{PKC}$ activity than controls, which is reversed after lithium treatment [44]. Brain slices from lithium-fed rats displayed inhibited stimulus-induced membrane translocation of PKC without affecting its baseline activity [42]. Moreover, PKC is pharmacologically activated by PMA, which provides DAG substitute [45]. PKC activation by direct infusion of PMA in the PFC of rodents and monkeys was shown to induce distractibility, impaired judgment, impulsivity, and thought disorder, which are characteristic symptoms of BD [46]. Furthermore, in rodents, infusion of PMA in the hippocampus, but not in lateral ventricle, was also found to have antidepressant-like effects, and induce enhanced risk-taking behavior [8].

With the development of animal models of mania in the past 2 decades, the involvement of $\mathrm{PKC}$ in manic phenotype has become more apparent. Increased PKC activity is observed in the PFC of rats submitted to AMPH administration $[47,48]$. AMPH-induced hyperlocomotion has been shown to be reversed [7] and prevented [49] by intraperitoneal administration of lithium or tamoxifen (TMX), a selective estrogen receptor modulator with PKC inhibitory activity $[8,50]$. Similarly, intraperitoneal administration of quercetin, a nonspecific
PKC inhibitor, also prevented methylphenidate-induced hyperlocomotion [51]. Not only in the presence of pharmacological intervention, daily intraperitoneal administration of lithium or TMX alone for 7 days significantly decreases phosphorylated PKC (pPKC) in the hippocampus, PFC, amygdala, and striatum [7]. Furthermore, chronic administration (14 days) of TMX caused depressive-like behavior in the forced swim test, and resulted in a reduction of cell proliferation in the dentate gyrus of the hippocampus [8].

Sleep-deprived rats display paradoxical hyperlocomotion, increased penile erection, and insomnia [48]. Sleepdeprived animals did not display manic phenotype when they were pretreated with lithium or TMX or their combination [52]. Intraperitoneal administration of quercetin also prevented PSD-induced hyperlocomotion [53]. Interestingly, PSD-induced behavioral changes were reversed by a one-time administration of lithium about $1 \mathrm{~h}$ prior to behavioral testing without affecting baseline activity [48]. At cellular level, PSD decreased hippocampal cell proliferation as indicated by decreased bromodeoxyuridine labeling [48]. Again, single administration of lithium increased BrdU-labeled hippocampal neurons in sleep-deprived rats highlighting potent neuroprotective actions of lithium [48]. 
Table 2. Summary of the in vivo studies

\begin{tabular}{|c|c|c|c|c|}
\hline $\begin{array}{l}\text { First author [Ref.], } \\
\text { year }\end{array}$ & Model & Design & Duration & Main findings \\
\hline Wang [34], 1989 & $\begin{array}{l}\text { Rat brain parietal } \\
\text { cortical slices }\end{array}$ & $\begin{array}{l}\text { Phorbol ester (PKC } \\
\text { activator) }\end{array}$ & 20-min incubation & $\begin{array}{l}\text { Induced dose-dependent increase in } \mathrm{K}^{+} \\
\text {induced } 5 \mathrm{HT} \text { release from cortical slices; } \\
\text { this phorbol ester facilitation was } \\
\text { prevented by PKC inhibitor }\end{array}$ \\
\hline Chen [39], 2000 & $\begin{array}{l}\text { Male Sprague- } \\
\text { Dawley rats and } \\
\text { Male C57 BL/6 } \\
\text { mice }\end{array}$ & $\begin{array}{l}\text { Lithium and VPA } \\
\text { treatment }\end{array}$ & $3-4$ weeks & $\begin{array}{l}\text { Lithium and VPA decreased plasma } \\
\text { membrane-associated PKC alpha and } \\
\text { PKC epsilon, increased DNA binding of } \\
\text { AP-1 and expression of AP-1-regulated } \\
\text { genes }\end{array}$ \\
\hline Wang [42], 2001 & $\begin{array}{l}\text { Male Sprague- } \\
\text { Dawley rats }\end{array}$ & $\begin{array}{l}\text { Food pellets containing } \\
0.212 \%(\mathrm{w} / \mathrm{w}) \text { lithium } \\
\text { chloride }\end{array}$ & 3 or 6 weeks & $\begin{array}{l}\text { In brain slices, lithium treatment } \\
\text { inhibited PMA-, 5HT-, or potassium- } \\
\text { induced PKC translocation from cytosol } \\
\text { to membrane without affecting basal } \\
\text { membrane or cytosolic PKC activity }\end{array}$ \\
\hline $\begin{array}{l}\text { Kirshenboim [132], } \\
2004\end{array}$ & C57Bl/6J mice & $\begin{array}{l}\text { ICV injection of } \\
\text { lithium }\end{array}$ & $3 \mathrm{~h}$ & $\begin{array}{l}\text { ICV injection of lithium increased } \\
\text { GSK-3beta Ser- } 9 \text { phosphorylation and } \\
\text { enhanced PKC alpha activity by } 1.8 \text {-fold } \\
\text { in mouse hippocampus }\end{array}$ \\
\hline Szabo [47], 2009 & $\begin{array}{l}\text { Amphetamine- } \\
\text { induced mania; } \\
\text { imipramine- } \\
\text { induced mania; } \\
\text { paradoxical sleep } \\
\text { deprivation }\end{array}$ & $\begin{array}{l}\text { Lithium treatment } \\
1.2 \text { and } 2.4 \mathrm{~g} / \mathrm{kg}\end{array}$ & 4 weeks & $\begin{array}{l}\text { PKC activity was increased in sleep- } \\
\text { deprived and amphetamine-treated rats; } \\
\text { increased PKC mediated } \\
\text { phosphorylation of neurogranin, NMDA } \\
\text { receptor site GluN1S896, and AMPA } \\
\text { receptor site GluA1T840 in PFC of sleep- } \\
\text { deprived and imipramine-treated rats; } \\
\text { effects were reversed in lithium-treated } \\
\text { animals; imipramine treatment enhanced } \\
\text { phospho-MARCKS in PFC }\end{array}$ \\
\hline Barbier [167], 2009 & $\begin{array}{l}\text { PKCI/HINT1 } \\
\text { knockout mice }\end{array}$ & - & - & $\begin{array}{l}\text { PKCI/HINT1 knockout mice display } \\
\text { anxiolytic-like and anti-depressant like } \\
\text { behavior and elevated corticosterone in } \\
\text { plasma }\end{array}$ \\
\hline Hains [174], 2009 & $\begin{array}{l}\text { Chronic stress } \\
\text { model; male } \\
\text { Sprague-Dawley } \\
\text { rats }\end{array}$ & $\begin{array}{l}\text { Chelerythrine } \\
1.0 \mathrm{mg} / \mathrm{kg} \text { s.c. }\end{array}$ & 21 days & $\begin{array}{l}\text { PKC inhibition prior to daily stress, } \\
\text { protected working memory and distal } \\
\text { apical dendritic spine loss in lay II/III } \\
\text { pyramidal neurons (greater spine } \\
\text { density) of rat prelimbic cortex induced } \\
\text { by daily stress }\end{array}$ \\
\hline $\begin{array}{l}\text { Cechinel-Recco [7], } \\
2012\end{array}$ & $\begin{array}{l}\text { Amphetamine- } \\
\text { induced mania }\end{array}$ & $\begin{array}{l}\text { Lithium }(47.5 \mathrm{mg} / \mathrm{kg}) \\
\text { and TMX }(1 \mathrm{mg} / \mathrm{kg}) \\
\text { i.p. }\end{array}$ & $\begin{array}{l}\text { Reversal model ( } 7 \\
\text { days); prevention } \\
\text { model (14 days) }\end{array}$ & $\begin{array}{l}\text { Lithium and TMX reversed and prevented } \\
\text { d-AMPH-induced hyperactivity; lithium } \\
\text { and TMX treatment reversed and } \\
\text { prevented the increase in PKC alpha } \\
\text { phosphorylation induced by d-AMPH }\end{array}$ \\
\hline Armani [52], 2012 & $\begin{array}{l}\text { Paradoxical sleep } \\
\text { deprivation }\end{array}$ & $\begin{array}{l}\text { Lithium }(50-150 \mathrm{mg} / \\
\mathrm{kg}) \text { and TMX }(0.5-2.0 \\
\mathrm{mg} / \mathrm{kg})\end{array}$ & 9 days & $\begin{array}{l}\text { Sleep deprivation induced hyperactivity } \\
\text { in mice that was prevented by lithium, } \\
\text { TMX and combination treatment }\end{array}$ \\
\hline Steckert [50], 2012 & $\begin{array}{l}\text { Amphetamine- } \\
\text { induced mania }\end{array}$ & TMX (1 mg/kg), i.p. & $\begin{array}{l}\text { Reversal model ( } 7 \\
\text { days); prevention } \\
\text { model (14 days) }\end{array}$ & $\begin{array}{l}\text { TMX reversed and prevented d-AMPH } \\
\text { induced behavioral effects via inhibition } \\
\text { of } \mathrm{PKC} \text { and prevention of oxidative stress }\end{array}$ \\
\hline
\end{tabular}


Table 2 (continued)

\begin{tabular}{|c|c|c|c|c|}
\hline $\begin{array}{l}\text { First author [Ref.], } \\
\text { year }\end{array}$ & Model & Design & Duration & Main findings \\
\hline Abrial [8], 2013 & $\begin{array}{l}\text { Amphetamine- } \\
\text { induced mania }\end{array}$ & $\begin{array}{l}\text { TMX ( } 10 \text { or } 80 \mathrm{mg} / \mathrm{kg} \text {, } \\
\text { i.p.) and chelerythrine } \\
(3 \mathrm{mg} / \mathrm{kg} \text { s.c.); PMA } \\
\text { (intracerebrally } \\
\text { administered acutely) }\end{array}$ & $\begin{array}{l}\text { TMX and } \\
\text { chelerythrine }(60 \\
\text { min before the } \\
\text { AMPH) } \\
\text { PMA ( } 40 \text { or } 10 \mathrm{~min} \\
\text { before the test) }\end{array}$ & $\begin{array}{l}\text { TMX and chelerythrine prevented } \\
\text { AMPH-induced hyperactivity and risk } \\
\text { taking behavior, and caused depressive- } \\
\text { like behavior; PMA (PKC activator) had } \\
\text { antidepressant-like effects }\end{array}$ \\
\hline Pereira [9], 2014 & $\begin{array}{l}\text { Amphetamine- } \\
\text { induced mania }\end{array}$ & $\begin{array}{l}\text { TMX }(1 \mathrm{mg} / \mathrm{kg}) \text {, } \\
\text { lithium }(100 \mathrm{mg} / \mathrm{kg}) \text {, } \\
\text { and myricitrin }(10 \text { and } \\
30 \mathrm{mg} / \mathrm{kg})\end{array}$ & - & $\begin{array}{l}\text { TMX, lithium, and myricitrin (PKC } \\
\text { inhibitor) reduced appetitive } 50-\mathrm{kHz} \\
\text { calls (proposed to be model euphoric } \\
\text { mood and pressured speech of human } \\
\text { mania) }\end{array}$ \\
\hline Abrial [48], 2014 & $\begin{array}{l}\text { Paradoxical sleep } \\
\text { deprivation in rats }\end{array}$ & PKC inhibitors & Acute injection & $\begin{array}{l}\text { PSD induced mania, increased SNAP } 25 \\
\text { in hippocampus and PFC suggesting } \\
\text { PKC hyperactivity; PKC inhibitors } \\
\text { attenuated manic behavior and rescued } \\
\text { hippocampal cell proliferation deficits } \\
\text { induced by PSD }\end{array}$ \\
\hline Kanazawa [53], 2016 & $\begin{array}{l}\text { Paradoxical sleep } \\
\text { deprivation; male } \\
\text { Swiss mice }\end{array}$ & $\begin{array}{l}\text { Quercetin (10 or } 40 \\
\text { mg/kg, i.p.) }\end{array}$ & Acute injection & $\begin{array}{l}\text { PSD-induced hyperactivity and lipid } \\
\text { peroxidation in PFC, hippocampus, and } \\
\text { striatum were prevented by quercetin }\end{array}$ \\
\hline Kanazawa [51], 2017 & $\begin{array}{l}\text { Methylphenidate- } \\
\text { induced mania }\end{array}$ & $\begin{array}{l}\text { Lithium }(100 \mathrm{mg} / \mathrm{kg}) \\
\text { and diazepam }(5 \mathrm{mg} / \\
\mathrm{kg})\end{array}$ & $\begin{array}{l}\text { Acute and chronic } \\
\text { (21 days) protocol }\end{array}$ & $\begin{array}{l}\text { Acute and } 21 \text { days of treatment with } \\
\text { lithium and diazepam reversed } \\
\text { methylphenidate-induced } \\
\text { hyperlocomotion and oxidative stress in } \\
\text { PFC, hippocampus, and striatum; } \\
\text { quercetin blocked methylphenidate- } \\
\text { induced hyperactivity without affecting } \\
\text { spontaneous locomotor activity }\end{array}$ \\
\hline
\end{tabular}

5HT, serotonin; VPA, valproic acid; AP-1, activator protein 1; PMA, phorbol 12-myristate, 13-acetate; GSK, glycogen synthase kinase; PSD, paradoxical sleep deprivation; PKCI/HINT1, PKC interacting protein/histidine triad nucleotide binding protein 1; AMPH, amphetamine; d-Amph, dextro-amphetamine; TMX, tamoxifen; PFC, prefrontal cortex; SNAP, synaptosomal-associated protein 25.

Pereira et al. [9] observed that AMPH increases appetitive $50-\mathrm{kHz}$ USV. The USV are emitted by rodents in association with social communication and reward behavior such as mating [54]. The authors, hence, reasonably propose that AMPH-induced increase in USV simulates euphoric affect and pressured speech that is observed in patients with BD during acute mania [9]. In support of its predictive validity, pretreatment of rats with Li or TMX blocked the increase in USV calls induced by AMPH without affecting spontaneous call rates or locomotor activity [9]. Myricitrin, another PKC inhibitor, also prevented the increased USV induced by AMPH in a dose-dependent manner without affecting baseline call rate at any of the doses used [9].
PKC is also commonly inhibited by chelerythrine, a benzophenanthridine alkaloid that was identified as a selective PKC inhibitor in 1990 [55]. Since then, it is widely used to investigate the role of PKC in several biological systems such as neuro- and cancer biology [56]. After several years of controversy regarding its selectivity [57-59], it has recently been shown that chelerythrine influences intracellular calcium homeostasis independent of PKC [60]. In animal models of mania, administration of chelerythrine prevented manic phenotype induced by AMPH [8]. While inhibition of PKC was concluded as the underlying mechanism by the authors, it is plausible that its effect on calcium homeostasis may have been involved in this observation [61]. In support of this alternative expla-
Mol Neuropsychiatry 2017;3:108-124
DOI: $10.1159 / 000480349$
Saxena/Scaini/Bavaresco/Leite/ Valvassoria/Carvalho/Quevedo 
Table 3. Summary of the human studies

\begin{tabular}{|c|c|c|}
\hline First author [Ref.], year & Sample & Main findings \\
\hline Friedman [44], 1993 & $\begin{array}{l}\text { Platelets from patients } \\
\text { with BD }\end{array}$ & $\begin{array}{l}\text { Increased PKC activity in manic patients; lithium treatment decreased PKC } \\
\text { activity in plasma membrane and cytosolic fractions }\end{array}$ \\
\hline Wang [65], 1996 & $\begin{array}{l}\text { Postmortem cortical } \\
\text { homogenate }\end{array}$ & $\begin{array}{l}\text { Increased PKC level and membrane-bound PKC activity in samples from } \\
\text { patients with BD in comparison with healthy controls }\end{array}$ \\
\hline Wang [68], 1999 & $\begin{array}{l}\text { Platelets from patients } \\
\text { with BD }\end{array}$ & $\begin{array}{l}\text { Basal PKC activity in platelets BD patients during acute manic episode was } \\
\text { higher in membrane fraction than control, depressed, or schizophrenic subjects }\end{array}$ \\
\hline Soares [69], 2000 & $\begin{array}{l}\text { Platelets from patients } \\
\text { with BD }\end{array}$ & $\begin{array}{l}\text { Platelets from lithium-treated euthymic BD patients had lower cytosolic PKC } \\
\text { alpha isozyme and PIP2 membrane levels }\end{array}$ \\
\hline Wang [67], 2001 & $\begin{array}{l}\text { Postmortem cortical } \\
\text { homogenate }\end{array}$ & $\begin{array}{l}\text { Increased RACK-1 association (membrane anchor) of PKC in samples from } \\
\text { patients with BD in comparison with healthy controls }\end{array}$ \\
\hline Pandey [171], 2002 & $\begin{array}{l}\text { Platelets from patients } \\
\text { with BD }\end{array}$ & $\begin{array}{l}\text { Platelets had decreased expression of PKC alpha, beta-I, beta-II, and PLC delta } \\
\text { isozyme in membrane and cytosol fractions but not of unipolar depression; } \\
\text { however, MARCKS was significantly elevated in membrane and cytosol fraction } \\
\text { in patients with BD }\end{array}$ \\
\hline Hahn [175], 2005 & $\begin{array}{l}\text { Platelets from patients } \\
\text { with BD }\end{array}$ & $\begin{array}{l}\text { Platelets from BD patients have increased basal membrane to cytosol PKC ratio } \\
\text { in comparison to control; BD subjects had higher translocation of PKC with } \\
\text { serotonin, thrombin, and PMA in comparison with control; lithium and VPA } \\
\text { attenuated stimulus induced translocation of PKC }\end{array}$ \\
\hline Akimoto [176], 2007 & $\begin{array}{l}\text { Platelets from patients } \\
\text { with BD }\end{array}$ & $\begin{array}{l}\text { Exaggerated PKC stimulation induced calcium influx; in controls PKC had } \\
\text { inhibitory effect on calmodulin system regulated capacitive calcium entry; in } \mathrm{BD} \\
\text { subjects, this inhibitory effect of PKC was enhanced }\end{array}$ \\
\hline Pandey [177], 2008 & $\begin{array}{l}\text { Platelets from pediatric } \\
\text { patients with } \mathrm{BD}\end{array}$ & $\begin{array}{l}\text { Platelets had decreased expression and activity of PKC beta-I, beta-II, but not } \\
\text { PKC alpha or PKC delta; } 8 \text { weeks of treatment with mood stabilizers normalized } \\
\text { or increased these observations }\end{array}$ \\
\hline Perlis [170], 2010 & $\begin{array}{l}\text { Genome-wide } \\
\text { association study }\end{array}$ & $\begin{array}{l}\text { Suicide attempt in BD patients: GWAS meta-analysis of 8,700 mood disorder } \\
\text { subjects identified association with multiple loci including PKC epsilon }\end{array}$ \\
\hline Carroll [141], 2010 & Genetic linkage study & $\begin{array}{l}\text { SNP in PKC alpha may play a role in pedigree analysis of psychotic and mood } \\
\text { disorder }\end{array}$ \\
\hline $\begin{array}{l}\text { Kandaswamy [142], } \\
2012\end{array}$ & Genetic linkage study & $\begin{array}{l}\text { Genotyped } 4 \text { microsatellite markers and } 9 \text { SNPs; PKC zeta may play a role in } \\
\text { susceptibility to BD }\end{array}$ \\
\hline $\begin{array}{l}\text { Le-Niculescu [172], } \\
2013\end{array}$ & $\begin{array}{l}\text { Convergent functional } \\
\text { genomics }\end{array}$ & $\begin{array}{l}\text { (1) No SI to high SI - differentially expressed genes are identified; (2) CFG - } \\
\text { prioritize genes to relevance to suicidality; (3) expression of these genes in blood } \\
\text { of live BD vs. suicide completers; found 13/41 show relevance from no SI to } \\
\text { high SI to completers, } 6 / 13 \text { significant; (4) SAT1, PTEN, MARCKS, MAP3K3 } \\
\text { differentiated past and future hospitalization in patients with BD }\end{array}$ \\
\hline $\begin{array}{l}\text { Kittel-Schneider [163], } \\
2016\end{array}$ & $\begin{array}{l}\text { Proof of concept study: } \\
\text { mRNA from peripheral } \\
\text { blood and fibroblasts of } \\
\text { heterozygote DGKH } \\
\text { risk variants carrier } \\
\text { with BD and non-risk } \\
\text { variant carriers with } \\
\text { and without BD }\end{array}$ & $\begin{array}{l}\text { DGKH1 expression was increased in peripheral blood of risk variant carriers; } \\
\text { PKCD expression was significantly elevated in fibroblasts from DGKH risk } \\
\text { variant carriers; current depressive episode had lower PKC delta levels, and } \\
\text { lithium treatment was found to be associated with elevated PKC alpha levels }\end{array}$ \\
\hline
\end{tabular}

BD, bipolar disorder; PIP2, phosphatidylinositol-4,5-bisphosphate; RACK-1, receptor for activated C kinase-1; PLC, phospholipase C; MARCKS, myristoylated alanine-rich C-kinase substrate; PMA, phorbol esters (phorbol 12-myristate 13-acetate); GWAS, genomewide association study; SNP, single nucleotide polymorphism; SI, suicidal ideations; SAT1, spermidine/spermine N1-acetyltransferase; PTEN, phosphatase and tensin homolog (PTEN); MAP3K3, mitogen-activated protein kinase kinase kinase 3; DGKH, gene coding for diacylglycerol kinase; PKCD, gene coding for PKC delta; CFG, convergent functional genomics; VPA, valproic acid. 
Table 4. Summary of the clinical studies

\begin{tabular}{|c|c|c|c|c|c|}
\hline $\begin{array}{l}\text { First author } \\
\text { [Ref.], year }\end{array}$ & Study & Mood state & Treatment & Duration & Observation \\
\hline $\begin{array}{l}\text { Bebchuk [73], } \\
2000\end{array}$ & $\begin{array}{l}\text { Proof of } \\
\text { concept study }\end{array}$ & Mania & $\begin{array}{l}\text { Single-blind, open-label, add-on } \\
\text { (some patients were on no other } \\
\text { medications) }\end{array}$ & & $\begin{array}{l}\text { Rapid resolution of manic } \\
\text { symptoms }\end{array}$ \\
\hline $\begin{array}{l}\text { Kulkarni [78], } \\
2006\end{array}$ & $\begin{array}{l}\text { Pilot study: } \\
\text { double-blind, } \\
\text { placebo } \\
\text { controlled } \\
(n=13)\end{array}$ & $\begin{array}{l}\text { Mania or } \\
\text { hypomania }\end{array}$ & $\begin{array}{l}\text { Group 1: TMX } 40 \mathrm{mg} / \text { day; group } 2 \\
\text { MPA } 20 \mathrm{mg} / \text { day; and group } 3 \\
\text { placebo; adjunct to lithium or VPA }\end{array}$ & 28 days & $\begin{array}{l}\text { Mean CARS-M score change at } \\
\text { the end of trial: group } 1=-22.2 \pm \\
12.49, \text { group } 2=-13.0 \pm 10.76 \\
\text { group } 3=-8.50 \pm 7.3 ; 1 \text { vs. } 3 p< \\
0.05,2 \text { vs. } 3 p<0.01,1 \text { vs. } 2 p> \\
0.05\end{array}$ \\
\hline $\begin{array}{l}\text { Zarate [76], } \\
2007\end{array}$ & $\begin{array}{l}\text { Double-blind, } \\
\text { placebo } \\
\text { controlled } \\
(n=16)\end{array}$ & $\begin{array}{l}\text { Mania or } \\
\text { mixed state }\end{array}$ & $\begin{array}{l}\text { TMX monotherapy }(20-140 \mathrm{mg} / \\
\text { day) }\end{array}$ & 21 days & $\begin{array}{l}63 \% \text { response in TMX vs. } 13 \% \text { in } \\
\text { placebo group }\end{array}$ \\
\hline $\begin{array}{l}\text { Yildiz [75], } \\
2008\end{array}$ & $\begin{array}{l}\text { Double-blind, } \\
\text { placebo } \\
\text { controlled } \\
(n=50)\end{array}$ & $\begin{array}{l}\text { Mania or } \\
\text { mixed state }\end{array}$ & $\begin{array}{l}\text { TMX } 80 \mathrm{mg} / \text { day vs. placebo; } \\
\text { lorazepam: pro re nata use of } \\
\text { lorazepam up to } 5 \mathrm{mg} / \text { day allowed, } \\
\text { avoided after } 12 \text { days, and not } \\
\text { administered } 12 \mathrm{~h} \text { prior to YMRS }\end{array}$ & 21 days & $\begin{array}{l}\text { Mean decrease in YMRS: TMX }= \\
5.84 \pm 0.64 / \text { week vs. placebo }=1.5 \pm \\
0.73 / \text { week, } p<0.001\end{array}$ \\
\hline $\begin{array}{l}\text { Amrollahi [79], } \\
2011\end{array}$ & $\begin{array}{l}\text { Double-blind, } \\
\text { placebo } \\
\text { controlled } \\
(n=40)\end{array}$ & Mania & $\begin{array}{l}\text { Group A: lithium }(1-1.2 \mathrm{mEq} / \mathrm{L})+ \\
\text { TMX ( } 80 \mathrm{mg} / \text { day); group B: } \\
\text { lithium }(1-1.2 \mathrm{mEq} / \mathrm{L})+\text { placebo }\end{array}$ & 42 days & $\begin{array}{l}\text { YMRS score }- \text { group } A=3.15 \pm \\
1.78 \text {, group } \mathrm{B}=9.45 \pm 8.50 ; p< \\
0.01\end{array}$ \\
\hline $\begin{array}{l}\text { Kulkarni [77], } \\
2014\end{array}$ & $\begin{array}{l}\text { Double-blind, } \\
\text { placebo } \\
\text { controlled } \\
(n=51)\end{array}$ & Mania & $\begin{array}{l}\text { Group 1: TMX } 40 \mathrm{mg} / \text { day; group } 2 \\
\text { MPA } 20 \mathrm{mg} / \text { day; and group } 3 \\
\text { placebo; adjunct to lithium, VPA, } \\
\text { or carbamazepine, and/or mood- } \\
\text { stabilizing antipsychotic }\end{array}$ & 28 days & $\begin{array}{l}\text { CARS-M scores decreased more } \\
\text { quickly in group } 2 \text { (MPA); no } \\
\text { significant difference in mean } \\
\text { CARS-M score change across } \\
\text { groups at the end of trial; MPA } \\
\text { but not TMX was beneficial in } \\
\text { treating acute mania in women }\end{array}$ \\
\hline $\begin{array}{l}\text { Yildiz [87], } \\
2016\end{array}$ & $\begin{array}{l}\text { Double blind, } \\
\text { placebo } \\
\text { controlled } \\
(n=48)\end{array}$ & Mania & $\begin{array}{l}\text { MRS scan at baseline and after } 3 \\
\text { weeks of treatment }\end{array}$ & 21 days & $\begin{array}{l}\text { TMX increased marker of brain } \\
\text { energy metabolism (total } \\
\text { creatinine) and neuronal viability } \\
\text { (NAA) in the dorsomedial PFC }\end{array}$ \\
\hline $\begin{array}{l}\text { Ahmad [82], } \\
2016\end{array}$ & $\begin{array}{l}\text { Double blind, } \\
\text { active-controlled } \\
\text { trial }(n=84)\end{array}$ & $\begin{array}{l}\text { Mania or } \\
\text { mixed state }\end{array}$ & $\begin{array}{l}\text { Endoxifen }(4 \mathrm{mg} / \text { day or } 8 \mathrm{mg} / \text { day }) \\
\text { or divalproex }(1,000 \mathrm{mg} / \text { day }) \text { in a } \\
2: 1 \text { ratio }\end{array}$ & 21 days & $\begin{array}{l}\text { Significant decrease in YMRS } \\
\text { score in as early as } 4 \text { days in } \\
\text { endoxifen group; the effect } \\
\text { remained significant throughout } \\
21 \text { days. Response rate } 45 \text { and } 65 \% \\
\text { at } 4 \text { and } 8 \mathrm{mg} \text { /day of endoxifen } \\
\text { treatment, respectively. }\end{array}$ \\
\hline $\begin{array}{l}\text { Talaei [13], } \\
2016\end{array}$ & $\begin{array}{l}\text { Meta-analysis of } \\
5 \text { randomized } \\
\text { controlled trials }\end{array}$ & n.a. & n.a. & n.a. & $\begin{array}{l}\text { TMX monotherapy-associated } \\
\text { difference in mean mania score } \\
\text { change was } 22.09(p<0.01) \text {; } \\
\text { pooled odds ratio of response to } \\
\text { TMX was } 15.36(95 \% \text { CI, } 2.99- \\
78.73 ; p=0.001)\end{array}$ \\
\hline
\end{tabular}

CARS-M, Clinician administered rating scale - Mania; MPA, medroxyprogesterone; TMX, tamoxifen; YMRS, Young Mania Rating Scale; MRS, magnetic resonance spectroscopy; NAA, N-acetylaspartate; VPA, valproic acid; PFC, prefrontal cortex. Mol Neuropsychiatry $2017 ; 3: 108-124$
DOI: $10.1159 / 000480349$
Saxena/Scaini/Bavaresco/Leite/

Valvassoria/Carvalho/Quevedo 
nation, increased intracellular $\mathrm{Ca}^{2+}$ ions have been observed in BD $[40,62,63]$. Verapamil, a calcium channel blocker with PKC inhibitory activity, is reported to significantly improve manic symptoms when combined with lithium [64].

\section{Clinical Studies}

In patients with $\mathrm{BD}, \mathrm{PKC}$ activity is studied mostly in the postmortem brain sample and platelets (usually during acute manic episode). A study in cortical homogenates of patients with $\mathrm{BD}$ showed that PKC levels and membrane-bound PKC activity were found to be increased in comparison with healthy controls [65]. PKC is anchored in the membrane by receptor for activated $\mathrm{C}$ kinase-1 (RACK-1) [66]. In frontal cortical homogenate, membrane PKC was found to be associated more with RACK-1 in BD samples [67]. Furthermore, in vitro stimulation of PKC by PMA produced enhanced stimulusinduced association between PKC and RACK-1 in samples from BD subjects in comparison to matched controls [67]. Platelets from manic patients also show higher membrane-bound PKC activity in comparison with healthy controls and patients with depression and schizophrenia [40, 68]. Moreover, chronic treatment with lithium has been observed to decrease both cytosolic and membrane-bound PKC levels in platelets from patients with BD [69].

Further support to PKC hyperactivity in BD is drawn from the use of TMX in human BD patients. TMX is a prodrug with little affinity towards estrogen receptor, but its metabolites have high affinity and compete with estrogen for binding [70]. TMX also displays PKC inhibitory activity [71] and is the only PKC inhibitor that crosses the blood brain barrier [72]. In 2000, Bebchuk et al. [73] reported a proof-of-concept study in which TMX resolved acute manic symptoms in humans for the first time. Since then, several small-scale clinical trials have been conducted to test the utility of TMX in BD management [74-77]. Patients with BD managed with TMX for 3 weeks showed a marked improvement in their manic presentation in as early as 5 days, an effect that remained significantly different throughout the 3-week trial [76]. TMX is also effective as an adjunct to lithium or valproic acid [78]. In a longer double-blind, randomized, placebo-controlled 6-week study, it was demonstrated that the combination of TMX with Li was superior to Li alone for the rapid reduction of manic symptoms [79]. Furthermore, TMX has also been reported to be an effective antimanic treatment in pediatric population [80]. In a recent meta-analysis, TMX was found to be effective as monotherapy and as an

Role of PKC in Bipolar Disorder adjunctive treatment for manic symptoms [13]. Recently, monotherapy with endoxifen, a metabolite of TMX and a potent PKC inhibitor [81], was found to be as effective as with valproic acid (extended release $1,000 \mathrm{mg} /$ day) in mitigation of manic symptoms [82]. Interestingly, medroxyprogesterone acetate, a progestin, also shows significant improvement in mania symptoms and may have a therapeutic utility in the future $[77,78]$.

$\mathrm{BD}$ is also associated with inefficient energy homeostasis in the brain, including decreases in mitochondrial respiration, high-energy phosphates, $\mathrm{pH}$, along with changes in mitochondrial morphology, increases in mitochondrial DNA polymorphisms, downregulation of nuclear mRNA molecules and proteins involved in mitochondrial respiration [83-85], and decreased neuronal viability marker, $\mathrm{N}$-acetylaspartate (NAA) [86]. Recently, in a double-blind placebo-controlled magnetic resonance spectroscopy study, TMX was shown to increase total creatinine and NAA in dorsomedial PFC in patients with $\mathrm{BD}$, suggesting enhanced neuronal viability [87].

In contrast to putative hyperactive PKC signaling in $\mathrm{BD}$, Young et al. [88] did not observe any significant difference in PKCa levels and activity between platelets from control, drug-free BD patients, and lithium-treated BD patients. In another contradictory finding in a recent report, Hayashi et al. [61] reported increased PKC activity in response to lithium in cultured adipocytes from patients with BD. These conflicting observations could be due to differences in patient characteristics and differences in tissues studied, respectively. In addition, the latter observation also implies that lithium may have tissuespecific actions on PKC signaling.

\section{Downstream Targets of PKC}

In addition to corroborating hyperactive PKC signaling in $\mathrm{BD}$, studying downstream targets of $\mathrm{PKC}$ in $\mathrm{BD}$ may yield additional therapeutic targets. We will discuss recent work that has identified key downstream substrates of PKC such as neurogranin, neurotrophic factors (NTFs), growth-associated protein 43 (GAP-43; and several aliases such as B-50, F1, and neuromodulin), myristoylated alanine-rich C-kinase substrate (MARCKS), synaptosomal-associated protein 25 (SNAP-25), along with effect of PKC on glutamatergic neurotransmission, oxidative stress, apoptotic, and cyclic AMP signaling (Fig. 1).

Neurogranin is a brain-specific calmodulin-binding protein that is expressed in the dendritic spines [47]. Neu-

Mol Neuropsychiatry 2017;3:108-124 DOI: $10.1159 / 000480349$ 


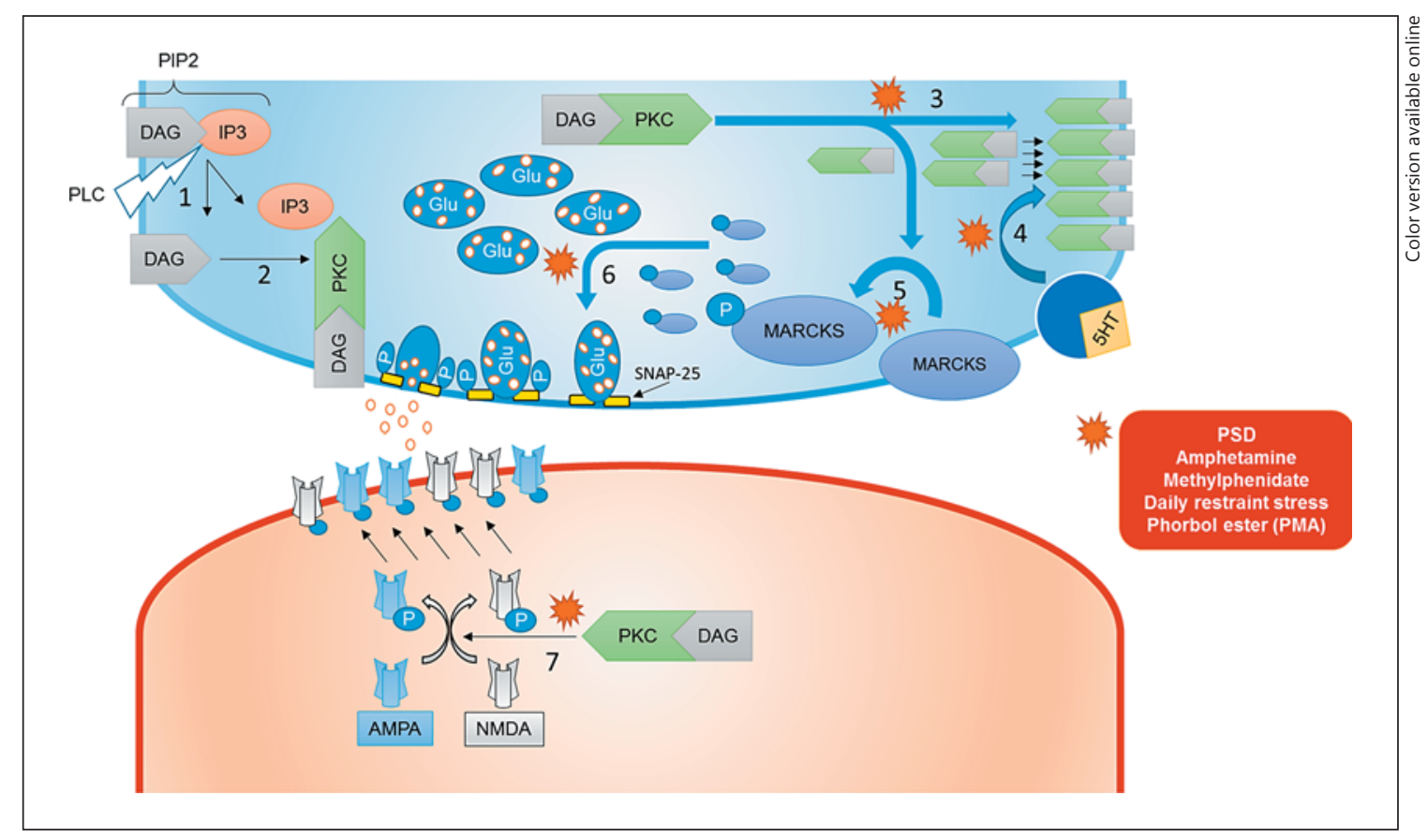

Fig. 1. Hypothetical schema of the effects of hyperactive protein kinase $\mathrm{C}$ (PKC) signaling in an animal model of bipolar disorder. 1 , activated phospholipase $\mathrm{C}$ dissociates phosphatidylinositol-4,5bisphosphate (PIP2) into diacylglycerol (DAG) and inositol triphosphate (IP3); 2, DAG as a cofactor activates PKC; 3, increased insertion of PKC in the membrane; 4 , increased stimulus-induced membrane translocation of PKC; 5 , increased myristoylated alanine-rich C-kinase substrate (MARCKS) phosphorylation; 6, increased membrane alignment of neurotransmitter-containing ves- icles; 6, increased phosphorylation of synaptosomal-associated protein 25 (SNAP-25) and increased neurotransmitter release; 7, increased alpha-amino-3-hydroxy-5-methyl-4-isoxazolepropionic acid (AMPA) and N-methyl-D-aspartate (NMDA) receptor phosphorylation and membrane insertion; $\mathrm{P}$, monophosphate/ phosphorylation; 5HT, serotonin; Glu, glutamate; PSD, paradoxical sleep deprivation; PMA, phorbol esters (phorbol 12-myristate 13-acetate); PLC, phospholipase C. rogranin is also a postsynaptic PKC substrate [89], regulates synaptic plasticity [90], and is implicated in schizophrenia $[91,92]$. In both AMPH and PSD models, along with imipramine treated rats, phosphorylation of neurogranin was increased [47]. Interestingly, neurogranin phosphorylation, which is associated with promanic interventions, was reversed by lithium [47]. Moreover, cultured hippocampal neurons have also been observed to lose their dendritic spines in response to sustained activation of PKC [93].

NTFs, such as brain-derived neurotrophic factor (BDNF), nerve growth factor (NGF), and neurotrophin-3, are observed to regulate gene expression and regulate synaptic plasticity via PKC signaling $[94,95]$. Furthermore, PKC not only acts as a second messenger but BDNF and NGF also modulate the activity of PKC [96, 97]. PKC, in turn, influence the expression of NTFs, such as NGF [98], BDNF [99], and glial cell line-derived neurotrophic factor [100]. These observations underscore the complexity and interdependence of these signaling cascades that fine-tune the synaptic strength. In vivo, AMPH-treated rats show increased PKC but decreased BDNF and NGF expression [7]. This reduction in NTFs was reversed by lithium and TMX [7]. Hence, although lithium may appear to decrease neuroplasticity markers such as MARCKS and GAP-43, it may enhance synaptic strength by increasing NTF expression. In addition, lithium also elongates cilia in PC12 neuronal cells and human astrocytes via cAMP singling pathway [101]. Also, lithium has been observed to promote synapse formation in hippocampus, independent of PKC activity [102]. Hence, lithium may partly influence neuroplasticity through PKC-independent mechanisms.

GAP-43 is also implicated in neurite outgrowth during neuronal differentiation and in synaptic plasticity [103, 104], since loss of function of GAP-43 inhibits neurotransmitter release [105]. GAP-43 is regulated by PKC protein, but it acts as an adaptor that binds to membrane 
lipid-rafts [106]. GAP-43 is also expressed in astrocytes and is also regulated by PKC [107]. GAP-43 levels are found to be decreased in postmortem samples of hippocampi from patients with $\mathrm{BD}$ in comparison with matched controls indicating impaired neuroplasticity [108]. On the other hand, lithium administration decreases GAP-43 expression in both immortalized hippocampal cell culture and in the frontal cortex and hippocampus through myo-inositol depletion [109]. However, its role in BD pathophysiology remains unknown, since the decrease in GAP-43 could be a treatment effect of lithium or an independent marker of impaired synaptic plasticity in $\mathrm{BD}$. Further research is needed to address these issues.

MARCKS is a membrane-bound actin crosslinking protein that regulates vesicular trafficking and mobility of structural phospholipids such as phosphatidylinositol-4,5-bisphosphate (PIP2) in the membrane plane [110, 111]. MARCKS undergoes dissociation from the membrane and translocates to cytoplasm after phosphorylation by PKC [112]. An increase in PKC-mediated phosphorylation of MARCKS (pMARCKS) in the PFC was observed in AMPH treatment and PSD models of mania [47]. In patients with $\mathrm{BD}$, treatment with tricyclic antidepressants (TCA) can often induce mania [113]. The administration of imipramine, a TCA, in rats increases the pMARCKS in the PFC [47]. Myo-inositol is an important component of PIP2 and provides the building blocks for inositol phosphate-mediated second messenger signaling [114]. Lithium treatment decreases the levels of MARCKS [115] through myo-inositol depletion [109]. Lithium also reversed the increase in pMARCKS in the PFC of AMPH and imipramine-treated and sleep-deprived rodents [47]. Valproic acid actions, on the other hand, are independent of myo-inositol [116] but also decrease MARCKS expression [117]. These observations highlight that although lithium and valproic acid have different mechanisms of actions, they share PKC as a target and affect its downstream signaling.

SNAP-25 is a t-SNARE protein that regulates neurotransmitter release by exocytosis [118] and is a major PKC substrate $[119,120]$. PKC activation with PMA has been shown to increase SNAP-25 phosphorylation and redistribute dopamine- and acetylcholine-containing vesicles to plasma membrane, along with increased depolarization-induced dopamine release [121]. Phosphorylation of SNAP-25 was increased in cerebral cortex, hippocampus, and amygdala of mice following cold-water restraint stress [120]. Interestingly, increased phosphorylation of SNAP-25 in both hippocampus and PFC was also seen in a PSD model of mania, suggesting increased

Role of PKC in Bipolar Disorder neurotransmitter release [48]. In fact, in support of this proposition, euthymic BD patients have been observed to have enhanced dopamine release compared with healthy subjects [122]. The effect of mood stabilizers or TMX on SNAP-25 phosphorylation, however, remains to be studied.

Glutamatergic excitotoxicity is another putative mechanisms proposed in BD pathophysiology [123]. A metaanalysis revealed that glutamate levels were increased in several brain regions of patients with BD [124]. Regarding glutamatergic signaling, AMPH-treated, sleep-deprived, and imipramine-treated rats showed that the increase in the phosphorylation of N-methyl-D-aspartate (GluN1S896) and alpha-amino-3-hydroxy-5-methyl-4isoxazolepropionic acid (GluA1T840) receptor in the PFC was PKC mediated, leading to an increase in trafficking of these receptors to neuronal membranes [47]. Moreover, the same study showed that these events were inhibited by chronic (3-week) lithium treatment, providing another explanation for antimanic properties of lithium [47].

Oxidative stress secondary to mitochondrial dysfunction is also implicated in BD pathophysiology [125]. In a meta-analysis, oxidative stress markers were observed to be increased in BD [126]. Quercetin is a flavanol that contains a polyphenolic structure that scavenges free radicals and hence, acts as an antioxidant, and it also exhibits pleiotropic nonspecific PKC inhibition [127]. Kanazawa et al. [53] showed that the quercetin administration was able to reverse the increase in lipid peroxidation in PFC, hippocampus, and striatum in a mouse model of mania induced by PSD. Quercetin also blocked methylphenidate-induced hyperlocomotion and oxidative stress in PFC, hippocampus, and striatum of mice [51]. It appears that oxidative stress is downstream to PKC signaling as TMX, a selective PKC inhibitor, also prevented and reversed oxidative stress in AMPH-treated rats [50].

GSK-3beta is a constitutively active kinase with high basal activity and inactivated by phosphorylation [128]. GSK was first characterized for its role in glycogen metabolism but later earned its major recognition in developmental and cancer biology [128]. GSK-3beta is inhibited by both lithium [129] and valproic acid [130]. Lithium directly inhibits GSK-3beta at supra-therapeutic levels [131] and indirectly, at therapeutically relevant concentration, through phosphorylation of its key inhibitory site, serine-9 via PI3-PKC pathway [132]. The effect of lithium on GSK-3beta expression, however, may be brain region dependent. For example, in a recent in vivo experiment, we observed that lithium treatment de-

Mol Neuropsychiatry 2017;3:108-124 DOI: $10.1159 / 000480349$ 
creased total GSK-3beta expression in PFC but increased it in the hippocampus [7]. Nevertheless, AMPH treatment significantly increased GSK-3beta expression and decreased phosphorylated GSK-3beta (pGSD-3beta - inactive form) in all mood-regulating frontolimbic structures [7], suggesting a GSK-3beta hyperactivity. Lithium and TMX administration reversed the AMPH-induced overactivation of GSK-3beta, suggesting that the increase in the GSK-3beta activity may be partly mediated by PKC [7]. Inhibition of GSK has also been shown to be neuroprotective by inhibition of apoptotic signaling and neurodegeneration [133], and is considered as one of the key future therapeutic avenues for BD [134].

The cyclic AMP (c-AMP)/protein kinase A (PKA)/cAMP response element binding protein (CREB) pathway plays an important role in synaptogenesis and synaptic plasticity [135]. Although the c-AMP /PKA/CREB pathway is not the focus of this review, it is important to note its cross-talk with phospholipase C (PLC)/PKC signaling pathway. The $\mathrm{G}$ protein-bound adenylate cyclase catalyzes the conversion of ATP into c-AMP, which activates $\mathrm{PKA}$, which in turn regulates several intracellular processes including phosphorylation of CREB, a transcription factor [136]. Increased c-AMP signaling is also implicated in BD [137-139]. In vivo microdialysis revealed that direct activation of PKC by PMA in the frontal cortex and hippocampus increases c-AMP in the dialysate [39]. Moreover, AMPH-treated rats show a decreased PKA and CREB phosphorylation in the frontolimbic circuit (PFC, hippocampus, amygdala, and striatum), and this decrease was prevented and reversed by lithium and TMX treatment [7].

\section{Genetics}

BD has high familial inheritability, and recent advances in genomic studies may provide insights into the genetic basis of BD [140]. Genetic studies have also implicated PKC in BD [141-143]. In the following section, we will briefly discuss putative gene candidates involving activator protein 1 (AP-1), GSK-3beta, DAG kinase eta (DGKeta), and PKC interacting protein/histidine triad nucleotide binding protein 1 (PKCI/HINT1), that highlight putative genetic mechanisms underlying BD.

AP-1 is a transcription factor, comprising Fos and Jun subunits [144], that regulates gene expression and neuroplasticity and is implicated in several chronic cardiovascular [145] and psychiatric illnesses [144]. AP-1 has been shown to increase its DNA binding in response to expo-

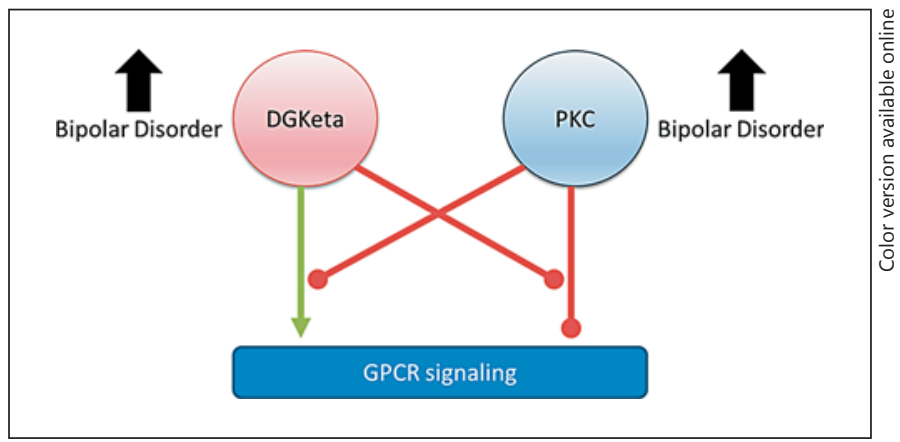

Fig. 2. Reciprocal regulation of intracellular diacylglycerol kinase eta (DGKeta) and protein kinase C (PKC) activity. DGKeta enhances G-protein coupled receptor (GPCR) signaling, and PKC inhibits GPCR signaling. DGKeta and PKC each reciprocally inhibit this action. Both PKC and DGKeta have been found to be elevated in bipolar disorder.

sure to lithium and valproic acid [146-148] and increase the translation of AP-1-regulated genes in vitro and in vivo $[39,116]$. Moreover, PKC signaling influences this key epigenetic effect by regulating phosphorylation Jun proteins [149].

DGKeta gained attention after several genome-wide association studies found DGKeta as one of the replicated risk genes in $\mathrm{BD}$ [150]. DGKeta is coded by DGKH gene, and polymorphisms in the DGKH gene have been observed to confer susceptibility to BD [151]. DGK risk haplotypes in humans are also associated with enlarged amygdala in BD patients [152]. Moreover, DGK is involved in biosynthesis of glycerophospholipids (GPLs) [153]. Alterations in membrane GPL composition has been implicated in several neuropsychiatric disorders, including BD [154]. DGKeta was observed to negatively regulate the PLC/PKC pathway by converting inactivating DAG, a cofactor of PKC, to phosphatidic acid [155157], hence preventing overactivation of PKC cascade. Recently, DGKeta and PKC have been shown to reciprocally inhibit each other [158]. Specifically, in HEK 293 cells, DGKeta overexpression increased and PKC activation decreased G-protein-coupled receptor (GPCR) signaling [158]. DGKeta overexpression prevented PKC activation-induced desensitization of GPCR signaling [158]. Pharmacological activation of PKC, in turn, prevented DGKeta overexpression-induced enhanced GPCR (muscarinic and purinergic) signaling [158] (Fig. 2). In the light of significant evidence in support of PKC hyperactivity in $\mathrm{BD}$, hypoactive DGKeta function can be hypothesized in BD [159]. In fact, DGKeta knockout mice
118

Mol Neuropsychiatry 2017;3:108-124 DOI: $10.1159 / 000480349$
Saxena/Scaini/Bavaresco/Leite/ Valvassoria/Carvalho/Quevedo 
display manic features that were ameliorated by lithium [160]. In contrast, patients with BD show increased DGKeta expression [161]. Given a reciprocal regulation between DGK and PKC [162], a compensatory increase in DGK expression can be hypothesized. However, future investigations are needed to further clarify the role of DGKeta in the pathophysiology of BD [163].

$\mathrm{PKCI} / \mathrm{HINT} 1$ is another gene candidate implicated in BD. PKCI/HINT1 is a haploinsufficient tumor suppressor gene [164]. In a meta-analysis, PKCI/HINT1 expression in dorsolateral PFC was found to be decreased in $\mathrm{BD}$ [165]. PKCI/HINT1 knockout mice do not show baseline hyperlocomotion but display enhanced locomotor response to AMPH treatment [166], increased risk-taking and antidepressant-like behavior [167], emotional arousal, and PKC expression [168]. As increased PKCI/HINT1 expression shows antineoplastic properties in colon and hepatic cells, a hypoactive PKCI/HINT1 may indicate activated neoplastic signaling that underlies BD [164].

Suicidality is a common occurrence in patients with $\mathrm{BD}$, and $\mathrm{PKC}$ is also implicated in suicidal behavior in patients with $\mathrm{BD}[169,170]$. In a meta-analysis of 8,700 patients, both unipolar depression and $\mathrm{BD}$ were found to be associated with suicidality and gene locus for PKCE [170]. Moreover, using the convergent functional genomics approach, MARCKS, a PKC substrate [171], was found to be one of the 6 peripheral biomarkers that predict past and future hospitalization in relation to suicidality in patients with BD [172]. This observation further implicates hyperactive PKC signaling in the etiopathogenesis of $\mathrm{BD}$.

\section{Conclusion}

An understanding of the pathogenesis of $\mathrm{BD}$ is needed to develop more effective therapies. Research in the past decade has identified several mechanisms such as apoptotic, neoplastic, inflammatory, energy homeostasis, synaptic neurotransmission, and oxidative balance to be involved in the pathophysiology of $\mathrm{BD}$. However, PKC appears to play a central role in all these processes [173]. This attribution is supported by the effectiveness of PKC inhibitors, such as TMX and endoxifen, in treating manic symptoms in humans. Nevertheless, future research is warranted to develop safe and specific therapies for this devastating disorder.

\section{Acknowledgments}

The Translational Psychiatric Program (USA) is funded by the Department of Psychiatry and Behavioral Sciences, The University of Texas Medical School at Houston. Laboratory of Neurosciences (Brazil) is one of the centers of the National Institute for Molecular Medicine (INCT-MM) and a member of the Center of Excellence in Applied Neurosciences of Santa Catarina (NENASC). This research was supported by grants from CNPq (J.L.Q., A.F.C., S.S.V.), FAPESC (J.L.Q.), Instituto Cérebro e Mente (J.L.Q.), and UNESC (J.L.Q. and S.S.V.). J.L.Q., A.F.C., and S.S.V. are $\mathrm{CNPq}$ Research Fellows.

\section{Disclosure Statement}

The authors declare that they have not had any financial, personal or other relationships that have influenced the work.

\section{References}

1 Muller-Oerlinghausen B, Berghofer A, Bauer M: Bipolar disorder. Lancet 2002;359:241247.

2 Green MJ, Cahill CM, Malhi GS: The cognitive and neurophysiological basis of emotion dysregulation in bipolar disorder. J Affect Disord 2007;103:29-42.

3 Grande I, Berk M, Birmaher B, Vieta E: Bipolar disorder. Lancet 2016;387:1561-1572.

4 Jope RS, Williams MB: Lithium and brain signal transduction systems. Biochem Pharmacol 1994;47:429-441.

5 McElroy SL, Keck PE Jr, Pope HG Jr, Hudson JI: Valproate in the treatment of bipolar disorder: literature review and clinical guidelines. J Clin Psychopharmacol 1992;12:42S$52 \mathrm{~S}$.
6 Sharma AN, Fries GR, Galvez JF, Valvassori SS, Soares JC, Carvalho AF, Quevedo J: Modeling mania in preclinical settings: a comprehensive review. Prog Neuropsychopharmacol Biol Psychiatry 2016;66:22-34.

7 Cechinel-Recco K, Valvassori SS, Varela RB, Resende WR, Arent CO, Vitto MF, Luz G, de Souza CT, Quevedo J: Lithium and tamoxifen modulate cellular plasticity cascades in animal model of mania. J Psychopharmacol 2012;26:1594-1604.

8 Abrial E, Etievant A, Betry C, Scarna H, Lucas G, Haddjeri N, Lambas-Senas L: Protein kinase $\mathrm{C}$ regulates mood-related behaviors and adult hippocampal cell proliferation in rats. Prog Neuropsychopharmacol Biol Psychiatry 2013;43:40-48.
9 Pereira M, Andreatini R, Schwarting RK, Brenes JC: Amphetamine-induced appetitive $50-\mathrm{kHz}$ calls in rats: a marker of affect in mania? Psychopharmacology 2014;231:25672577.

10 Nestler EJ, Hyman SE: Animal models of neuropsychiatric disorders. Nat Neurosci 2010; 13:1161-1169.

11 Brady RO, Keshavan M: Emergent treatments based on the pathophysiology of bipolar disorder: a selective review. Asian J Psychiatry 2015; 18:15-21.

12 Manji HK, Lenox RH: Long-term action of lithium: a role for transcriptional and posttranscriptional factors regulated by protein kinase C. Synapse 1994;16:11-28. 
13 Talaei A, Pourgholami M, Khatibi-Moghadam H, Faridhosseini F, Farhoudi F, AskariNoghani A, Sadeghi R: Tamoxifen: a protein kinase $\mathrm{C}$ inhibitor to treat mania: a systematic review and meta-analysis of randomized, placebo-controlled trials. J Clin Psychopharmacol 2016;36:272-275.

14 Zarate CA, Manji HK: Protein kinase C inhibitors: rationale for use and potential in the treatment of bipolar disorder. CNS Drugs 2009;23:569-582.

15 Kazi JU, Kabir NN, Soh JW: Bioinformatic prediction and analysis of eukaryotic protein kinases in the rat genome. Gene 2008;410: 147-153.

16 Kabir NN, Kazi JU: Comparative analysis of human and bovine protein kinases reveals unique relationship and functional diversity. Genet Mol Biol 2011;34:587-591.

17 Sanchez-Bautista S, Nicolas FE: Recent patents concerning modulators of protein kinase C. Recent Pat DNA Gene Seq 2013;7:74-81.

18 Ohno S, Nishizuka Y: Protein kinase C isotypes and their specific functions: prologue. J Biochem 2002;132:509-511.

19 Turner RS, Raynor RL, Mazzei GJ, Girard PR, Kuo JF: Developmental studies of phospholipid-sensitive $\mathrm{Ca}^{2+}$-dependent protein kinase and its substrates and of phosphoprotein phosphatases in rat brain. Proc Natl Acad Sci USA 1984;81:3143-3147.

20 Amadio M, Battaini F, Pascale A: The different facets of protein kinases $\mathrm{C}$ : old and new players in neuronal signal transduction pathways. Pharmacol Res 2006;54:317-325.

21 Naik MU, Benedikz E, Hernandez I, Libien J, Hrabe J, Valsamis M, Dow-Edwards D, Osman M, Sacktor TC: Distribution of protein kinase Mzeta and the complete protein kinase $\mathrm{C}$ isoform family in rat brain. J Comp Neurol 2000;426:243-258.

22 Wetsel WC, Khan WA, Merchenthaler I, Rivera $\mathrm{H}$, Halpern $\mathrm{AE}$, Phung HM, Negro-Vilar A, Hannun YA: Tissue and cellular distribution of the extended family of protein kinase C isoenzymes. J Cell Biol 1992;117:121-133.

23 Pahl S, Tapken D, Haering SC, Hollmann M: Trafficking of kainate receptors. Membranes 2014;4:565-595.

24 Zarate CA Jr, Singh J, Manji HK: Cellular plasticity cascades: targets for the development of novel therapeutics for bipolar disorder. Biol Psychiatry 2006;59:1006-1020.

25 Opazo F, Schulz JB, Falkenburger BH: PKC links Gq-coupled receptors to DAT-mediated dopamine release. J Neurochem 2010;114: 587-596.

26 Zarate CA Jr, Du J, Quiroz J, Gray NA, Denicoff KD, Singh J, Charney DS, Manji HK: Regulation of cellular plasticity cascades in the pathophysiology and treatment of mood disorders: role of the glutamatergic system. Ann NY Acad Sci 2003;1003:273-291.

27 Chu Y, Fioravante D, Leitges M, Regehr WG: Calcium-dependent PKC isoforms have specialized roles in short-term synaptic plasticity. Neuron 2014;82:859-871.
28 Nam Y, Wie MB, Shin EJ, Nguyen TT, Nah SY, Ko SK, Jeong JH, Jang CG, Kim HC: Ginsenoside Re protects methamphetamine-induced mitochondrial burdens and proapoptosis via genetic inhibition of protein kinase $\mathrm{C}$ delta in human neuroblastoma dopaminergic SH-SY5Y cell lines. J Appl Toxicol 2015;35: 927-944.

29 Hadley SH, Bahia PK, Taylor-Clark TE: Sensory nerve terminal mitochondrial dysfunction induces hyperexcitability in airway nociceptors via protein kinase C. Mol Pharmacol 2014;85:839-848.

30 Suganthy N, Devi KP, Nabavi SF, Braidy N, Nabavi SM: Bioactive effects of quercetin in the central nervous system: focusing on the mechanisms of actions. Biomed Pharmacother 2016;84:892-908.

31 Le-Niculescu H, Kurian SM, Yehyawi N, Dike C, Patel SD, Edenberg HJ, Tsuang MT, Salomon DR, Nurnberger JI Jr, Niculescu AB: Identifying blood biomarkers for mood disorders using convergent functional genomics. Mol Psychiatry 2009;14:156-174.

32 Jun C, Choi Y, Lim SM, Bae S, Hong YS, Kim JE, Lyoo IK: Disturbance of the glutamatergic system in mood disorders. Exp Neurobiol 2014;23:28-35.

33 Bitran JA, Potter WZ, Manji HK, Gusovsky F: Chronic Li+ attenuates agonist- and phorbol ester-mediated $\mathrm{Na}+\mathrm{H}+$ antiporter activity in HL-60 cells. Eur J Pharmacol 1990;188:193202.

34 Wang HY, Friedman E: Lithium inhibition of protein kinase C activation-induced serotonin release. Psychopharmacology 1989;99: 213-218.

35 Casebolt TL, Jope RS: Effects of chronic lithium treatment on protein kinase $\mathrm{C}$ and cyclic AMP-dependent protein phosphorylation. Biol Psychiatry 1991;29:233-243.

36 Klein E, Patel J, McDevitt R, Zohar J: Chronic lithium treatment increases the phosphorylation of a $64-\mathrm{kDa}$ protein in rat brains. Brain Res 1987;407:312-316.

37 Vatal M, Aiyar AS: Phosphorylation of brain synaptosomal proteins in lithium-treated rats. Biochem Pharmacol 1984;33:829-831.

38 Chen G, Manji HK, Hawver DB, Wright CB, Potter WZ: Chronic sodium valproate selectively decreases protein kinase $\mathrm{C}$ alpha and epsilon in vitro. J Neurochem 1994;63:23612364.

39 Chen G, Masana MI, Manji HK: Lithium regulates PKC-mediated intracellular cross-talk and gene expression in the CNS in vivo. Bipolar Disord 2000;2:217-236.

40 Hahn CG, Friedman E: Abnormalities in protein kinase $\mathrm{C}$ signaling and the pathophysiology of bipolar disorder. Bipolar Disord 1999; 1:81-86.

41 Soares JC, Mallinger AG: Intracellular phosphatidylinositol pathway abnormalities in bipolar disorder patients. Psychopharmacol Bull 1997;33:685-691.
42 Wang HY, Johnson GP, Friedman E: Lithium treatment inhibits protein kinase $\mathrm{C}$ translocation in rat brain cortex. Psychopharmacology 2001; 158:80-86.

43 Weiss S, Ellis J, Hendley DD, Lenox RH: Translocation and activation of protein kinase $\mathrm{C}$ in striatal neurons in primary culture: relationship to phorbol dibutyrate actions on the inositol phosphate generating system and neurotransmitter release. J Neurochem 1989; 52:530-536.

44 Friedman E, Hoau Yan W, Levinson D, Connell TA, Singh H: Altered platelet protein kinase C activity in bipolar affective disorder, manic episode. Biol Psychiatry 1993;33:520-525.

45 Sharkey NA, Leach KL, Blumberg PM: Competitive inhibition by diacylglycerol of specific phorbol ester binding. Proc Natl Acad Sci USA 1984;81:607-610.

46 Birnbaum SG, Yuan PX, Wang M, Vijayraghavan S, Bloom AK, Davis DJ, Gobeske KT, Sweatt JD, Manji HK, Arnsten AF: Protein kinase $\mathrm{C}$ overactivity impairs prefrontal cortical regulation of working memory. Science 2004;306:882-884.

47 Szabo ST, Machado-Vieira R, Yuan P, Wang Y, Wei Y, Falke C, Cirelli C, Tononi G, Manji $\mathrm{HK}, \mathrm{Du}$ J: Glutamate receptors as targets of protein kinase $\mathrm{C}$ in the pathophysiology and treatment of animal models of mania. Neuropharmacology 2009;56:47-55.

48 Abrial E, Betourne A, Etievant A, Lucas G, Scarna H, Lambas-Senas L, Haddjeri N: Protein kinase $\mathrm{C}$ inhibition rescues manic-like behaviors and hippocampal cell proliferation deficits in the sleep deprivation model of mania. Int $J$ Neuropsychopharmacol 2014;18:pyu031.

49 Einat H, Yuan P, Szabo ST, Dogra S, Manji HK: Protein kinase $\mathrm{C}$ inhibition by tamoxifen antagonizes manic-like behavior in rats: implications for the development of novel therapeutics for bipolar disorder. Neuropsychobiology 2007;55:123-131.

50 Steckert AV, Valvassori SS, Mina F, LopesBorges J, Varela RB, Kapczinski F, Dal-Pizzol F, Quevedo J: Protein kinase C and oxidative stress in an animal model of mania. Curr Neurovasc Res 2012;9:47-57.

51 Kanazawa LK, Vecchia DD, Wendler EM, Hocayen PA, Berao PS Jr, de Melo ML, Dos Reis Livero FA, Corso CR, Stipp MC, Acco A, Andreatini R: Effects of acute and chronic quercetin administration on methylphenidate-induced hyperlocomotion and oxidative stress. Life Sci 2017;171:1-8.

52 Armani F, Andersen ML, Andreatini R, Frussa-Filho R, Tufik S, Galduroz JC: Successful combined therapy with tamoxifen and lithium in a paradoxical sleep deprivation-induced mania model. CNS Neurosci Ther 2012;18:119-125.

53 Kanazawa LK, Vecchia DD, Wendler EM, Hocayen PA, Dos Reis Livero FA, Stipp MC, Barcaro IM, Acco A, Andreatini R: Quercetin reduces manic-like behavior and brain oxidative stress induced by paradoxical sleep deprivation in mice. Free Radic Biol Med 2016;99:79-86. 
54 Brudzynski SM: Principles of rat communication: quantitative parameters of ultrasonic calls in rats. Behav Genet 2005;35:85-92.

55 Herbert JM, Augereau JM, Gleye J, Maffrand JP: Chelerythrine is a potent and specific inhibitor of protein kinase C. Biochem Biophys Res Commun 1990;172:993-999.

56 Wu-Zhang AX, Newton AC: Protein kinase C pharmacology: refining the toolbox. Biochem J 2013;452:195-209.

57 Reshef A, Sperling O, Zoref-Shani E: Activation and inhibition of protein kinase $\mathrm{C}$ protect rat neuronal cultures against ischemia-reperfusion insult. Neurosci Lett 1997;238:37-40.

58 Voutilainen-Myllyla S, Tavi P, Weckstrom M: Chelerythrine and bisindolylmaleimide I prolong cardiac action potentials by protein kinase C-independent mechanism. Eur J Pharmacol 2003;466:41-51.

59 Lee SK, Qing WG, Mar W, Luyengi L, Mehta RG, Kawanishi K, Fong HH, Beecher CW, Kinghorn AD, Pezzuto JM: Angoline and chelerythrine, benzophenanthridine alkaloids that do not inhibit protein kinase C. J Biol Chem 1998;273:19829-19833.

60 Saavedra A, Fernandez-Garcia S, Cases S, Puigdellivol M, Alcala-Vida R, Martin-Flores N, Alberch J, Gines S, Malagelada C, PerezNavarro E: Chelerythrine promotes Ca2+-dependent calpain activation in neuronal cells in a PKC-independent manner. Biochim Biophys Acta 2017;1861:922-935.

61 Hayashi A, Le Gal K, Sodersten K, VizlinHodzic D, Agren H, Funa K: Calcium-dependent intracellular signal pathways in primary cultured adipocytes and ANK3 gene variation in patients with bipolar disorder and healthy controls. Mol Psychiatry 2015;20:931-940.

62 Dubovsky SL, Murphy J, Thomas M, Rademacher J: Abnormal intracellular calcium ion concentration in platelets and lymphocytes of bipolar patients. Am J Psychiatry 1992;149: 118-120.

63 Dubovsky SL, Daurignac E, Leonard KE, Serotte JC: Levetiracetam, calcium antagonism, and bipolar disorder. J Clin Psychopharmacol 2015;35:422-427.

64 Mallinger AG, Thase ME, Haskett R, Buttenfield J, Luckenbaugh DA, Frank E, Kupfer DJ, Manji HK: Verapamil augmentation of lithium treatment improves outcome in mania unresponsive to lithium alone: preliminary findings and a discussion of therapeutic mechanisms. Bipolar Disord 2008;10:856-866.

65 Wang HY, Friedman E: Enhanced protein kinase $\mathrm{C}$ activity and translocation in bipolar affective disorder brains. Biol Psychiatry 1996; 40:568-575.

66 Mochly-Rosen D, Khaner H, Lopez J: Identification of intracellular receptor proteins for activated protein kinase C. Proc Natl Acad Sci USA 1991;88:3997-4000.

67 Wang H, Friedman E: Increased association of brain protein kinase $\mathrm{C}$ with the receptor for activated C kinase-1 (RACK1) in bipolar affective disorder. Biol Psychiatry 2001;50:364370.
68 Wang HY, Markowitz P, Levinson D, Undie AS, Friedman E: Increased membrane-associated protein kinase $\mathrm{C}$ activity and translocation in blood platelets from bipolar affective disorder patients. J Psychiatr Res 1999;33: 171-179.

69 Soares JC, Chen G, Dippold CS, Wells KF, Frank E, Kupfer DJ, Manji HK, Mallinger AG: Concurrent measures of protein kinase $\mathrm{C}$ and phosphoinositides in lithium-treated bipolar patients and healthy individuals: a preliminary study. Psychiatry Res 2000;95:109-118.

70 Ahmad A, Shahabuddin S, Sheikh S, Kale P, Krishnappa M, Rane RC, Ahmad I: Endoxifen, a new cornerstone of breast cancer therapy: demonstration of safety, tolerability, and systemic bioavailability in healthy human subjects. Clin Pharmacol Ther 2010;88:814-817.

71 Gunosewoyo H, Yu L, Munoz L, Kassiou M: Kinase targets in CNS drug discovery. Future Med Chem 2017;9:303-314.

72 Carpenter C, Sorenson RJ, Jin Y, Klossowski S, Cierpicki T, Gnegy M, Showalter HD: Design and synthesis of triarylacrylonitrile analogues of tamoxifen with improved binding selectivity to protein kinase C. Bioorg Med Chem 2016;24:5495-5504.

73 Bebchuk JM, Arfken CL, Dolan-Manji S, Murphy J, Hasanat K, Manji HK: A preliminary investigation of a protein kinase $\mathrm{C}$ inhibitor in the treatment of acute mania. Arch Gen Psychiatry 2000;57:95-97.

74 Kruszewski SP, Paczynski R: Concomitant use of Lorazepam with tamoxifen in bipolar mania clinical trials. Arch Gen Psychiatry 2009;66:107-108; author reply 108-109.

75 Yildiz A, Guleryuz S, Ankerst DP, Ongur D, Renshaw PF: Protein kinase $C$ inhibition in the treatment of mania: a double-blind, placebo-controlled trial of tamoxifen. Arch Gen Psychiatry 2008;65:255-263.

76 Zarate CA Jr, Singh JB, Carlson PJ, Quiroz J, Jolkovsky L, Luckenbaugh DA, Manji HK: Efficacy of a protein kinase $\mathrm{C}$ inhibitor (tamoxifen) in the treatment of acute mania: a pilot study. Bipolar Disord 2007;9:561-570.

77 Kulkarni J, Berk M, Wang W, Mu L, Scarr E, Van Rheenen TE, Worsley R, Gurvich C, Gavrilidis E, de Castella A, Fitzgerald P, Davis SR: A four week randomised control trial of adjunctive medroxyprogesterone and tamoxifen in women with mania. Psychoneuroendocrinology 2014;43:52-61.

78 Kulkarni J, Garland KA, Scaffidi A, Headey B, Anderson R, de Castella A, Fitzgerald P, Davis SR: A pilot study of hormone modulation as a new treatment for mania in women with bipolar affective disorder. Psychoneuroendocrinology 2006;31:543-547.

79 Amrollahi Z, Rezaei F, Salehi B, Modabbernia AH, Maroufi A, Esfandiari GR, Naderi M, Ghebleh F, Ahmadi-Abhari SA, Sadeghi M, Tabrizi M, Akhondzadeh S: Double-blind, randomized, placebo-controlled 6-week study on the efficacy and safety of the tamoxifen adjunctive to lithium in acute bipolar mania. J Affect Disord 2011;129:327-331.
80 Fallah E, Arman S, Najafi M, Shayegh B: Effect of tamoxifen and lithium on treatment of acute mania symptoms in children and adolescents. Iranian J Child Neurol 2016;10:1625.

81 Ali SM, Ahmad A, Shahabuddin S, Ahmad MU, Sheikh S, Ahmad I: Endoxifen is a new potent inhibitor of PKC: a potential therapeutic agent for bipolar disorder. Bioorg Med Chem Lett 2010;20:2665-2667.

82 Ahmad A, Sheikh S, Shah T, Reddy MS, Prasad B, Verma KK, Chandrakant BB, Paithankar M, Kale P, Solanki RV, Patel R, Barkate H, Ahmad I: Endoxifen, a new treatment option for mania: a double-blind, active-controlled trial demonstrates the antimanic efficacy of endoxifen. Clin Transl Sci DOI: $10.1111 /$ cts. 12407.

83 Cataldo AM, McPhie DL, Lange NT, Punzell S, Elmiligy S, Ye NZ, Froimowitz MP, Hassinger LC, Menesale EB, Sargent LW, Logan DJ, Carpenter AE, Cohen BM: Abnormalities in mitochondrial structure in cells from patients with bipolar disorder. Am J Pathol 2010;177:575-585.

84 Dager SR, Friedman SD, Parow A, Demopulos C, Stoll AL, Lyoo IK, Dunner DL, Renshaw PF: Brain metabolic alterations in medication-free patients with bipolar disorder. Arch Gen Psychiatry 2004;61:450-458.

85 Scaini G, Rezin GT, Carvalho AF, Streck EL, Berk M, Quevedo J: Mitochondrial dysfunction in bipolar disorder: evidence, pathophysiology and translational implications. Neurosci Biobehav Rev 2016;68:694-713.

86 Kraguljac NV, Reid M, White D, Jones R, den Hollander J, Lowman D, Lahti AC: Neurometabolites in schizophrenia and bipolar disorder - a systematic review and meta-analysis. Psychiatry Res 2012;203:111-125.

87 Yildiz A, Aydin B, Gokmen N, Yurt A, Cohen B, Keskinoglu P, Ongur D, Renshaw P: Antimanic treatment with tamoxifen affects brain chemistry: a double-blind, placebo-controlled proton magnetic resonance spectroscopy study. Biol Psychiatry Cogn Neurosci Neuroimaging 2016;1:125-131.

88 Young LT, Wang JF, Woods CM, Robb JC: Platelet protein kinase $\mathrm{C}$ alpha levels in drugfree and lithium-treated subjects with bipolar disorder. Neuropsychobiology 1999;40:6366.

89 Baudier J, Deloulme JC, Van Dorsselaer A, Black D, Matthes HW: Purification and characterization of a brain-specific protein kinase $\mathrm{C}$ substrate, neurogranin ( $\mathrm{p} 17)$. Identification of a consensus amino acid sequence between neurogranin and neuromodulin (GAP43) that corresponds to the protein kinase C phosphorylation site and the calmodulinbinding domain. J Biol Chem 1991;266:229237.

90 Ran X, Miao HH, Sheu FS, Yang D: Structur$\mathrm{al}$ and dynamic characterization of a neuronspecific protein kinase $\mathrm{C}$ substrate, neurogranin. Biochemistry 2003;42:5143-5150. 
91 Ruano D, Aulchenko YS, Macedo A, Soares MJ, Valente J, Azevedo MH, Hutz $\mathrm{MH}$, Gama CS, Lobato MI, Belmonte-de-Abreu P, Goodman AB, Pato C, Heutink P, Palha JA: Association of the gene encoding neurogranin with schizophrenia in males. J Psychiatr Res 2008;42:125-133.

92 Broadbelt K, Ramprasaud A, Jones LB: Evidence of altered neurogranin immunoreactivity in areas 9 and 32 of schizophrenic prefrontal cortex. Schizophr Res 2006;87:6-14.

93 Calabrese B, Halpain S: Essential role for the PKC target MARCKS in maintaining dendritic spine morphology. Neuron 2005;48: 77-90.

94 Minichiello L, Korte M, Wolfer D, Kuhn R, Unsicker K, Cestari V, Rossi-Arnaud C, Lipp HP, Bonhoeffer T, Klein R: Essential role for TrkB receptors in hippocampus-mediated learning. Neuron 1999;24:401-414.

95 Arevalo JC, Wu SH: Neurotrophin signaling: many exciting surprises! Cell Mol Life Sci 2006;63:1523-1537.

96 Melemedjian OK, Tillu DV, Asiedu MN, Mandell EK, Moy JK, Blute VM, Taylor CJ, Ghosh S, Price TJ: BDNF regulates atypical $\mathrm{PKC}$ at spinal synapses to initiate and maintain a centralized chronic pain state. Mol Pain 2013;9:12.

97 Zhang YH, Kays J, Hodgdon KE, Sacktor TC, Nicol GD: Nerve growth factor enhances the excitability of rat sensory neurons through activation of the atypical protein kinase C isoform, PKMzeta. J Neurophysiol 2012;107:315-335.

98 Lee JG, Cho HY, Park SW, Seo MK, Kim YH: Effects of olanzapine on brain-derived neurotrophic factor gene promoter activity in SH-SY5Y neuroblastoma cells. Prog Neuropsychopharmacol Biol Psychiatry 2010;34: 1001-1006.

$99 \mathrm{Xu} \mathrm{H}$, Czerwinski P, Xia N, Forstermann U, Li H: Downregulation of BDNF expression by PKC and by TNF-alpha in human endothelial cells. Pharmacology 2015;96:1-10.

100 Xu P, Rosen KM, Hedstrom K, Rey O, Guha S, Hart C, Corfas G: Nerve injury induces glial cell line-derived neurotrophic factor (GDNF) expression in Schwann cells through purinergic signaling and the PKCPKD pathway. Glia 2013;61:1029-1040.

101 Ou Y, Ruan Y, Cheng M, Moser JJ, Rattner JB, van der Hoorn FA: Adenylate cyclase regulates elongation of mammalian primary cilia. Exp Cell Res 2009;315:2802-2817.

102 Kim HJ, Thayer SA: Lithium increases synapse formation between hippocampal neurons by depleting phosphoinositides. Mol Pharmacol 2009;75:1021-1030.

103 Fishman MC: GAP-43: putting constraints on neuronal plasticity. Perspect Dev Neurobiol 1996;4:193-198.

104 Pasinelli P, Ramakers GM, Urban IJ, Hens JJ, Oestreicher AB, de Graan PN, Gispen WH: Long-term potentiation and synaptic protein phosphorylation. Behav Brain Res 1995; 66:53-59.
105 Dekker LV, De Graan PN, Oestreicher AB, Versteeg DH, Gispen WH: Inhibition of noradrenaline release by antibodies to B-50 (GAP-43). Nature 1989;342:74-76.

106 Benowitz LI, Routtenberg A: GAP-43: an intrinsic determinant of neuronal development and plasticity. Trends Neurosci 1997; 20:84-91.

107 Deloulme JC, Janet T, Au D, Storm DR, Sensenbrenner M, Baudier J: Neuromodulin (GAP43): a neuronal protein kinase $\mathrm{C}$ substrate is also present in 0-2A glial cell lineage. Characterization of neuromodulin in secondary cultures of oligodendrocytes and comparison with the neuronal antigen. J Cell Biol 1990;111:1559-1569.

108 Tian SY, Wang JF, Bezchlibnyk YB, Young LT: Immunoreactivity of $43 \mathrm{kDa}$ growth-associated protein is decreased in post mortem hippocampus of bipolar disorder and schizophrenia. Neurosci Lett 2007;411:123127.

109 Manji HK, Bersudsky Y, Chen G, Belmaker $\mathrm{RH}$, Potter WZ: Modulation of protein kinase $\mathrm{C}$ isozymes and substrates by lithium: the role of myo-inositol. Neuropsychopharmacology 1996;15:370-381.

110 Prieto D, Zolessi FR: Functional diversification of the four MARCKS family members in zebrafish neural development. J Exp Zool B Mol Dev Evol 2017;328:119-138.

111 Ouimet CC, Wang JK, Walaas SI, Albert KA, Greengard P: Localization of the MARCKS $(87 \mathrm{kDa})$ protein, a major specific substrate for protein kinase $\mathrm{C}$, in rat brain. J Neurosci 1990;10:1683-1698.

112 Hartwig JH, Thelen M, Rosen A, Janmey PA, Nairn AC, Aderem A: MARCKS is an actin filament crosslinking protein regulated by protein kinase $\mathrm{C}$ and calcium-calmodulin. Nature 1992;356:618-622.

113 Peet M: Induction of mania with selective serotonin re-uptake inhibitors and tricyclic antidepressants. Br J Psychiatry 1994;164: 549-550.

114 Parthasarathy LK, Seelan RS, Tobias C, Casanova MF, Parthasarathy RN: Mammalian inositol 3-phosphate synthase: its role in the biosynthesis of brain inositol and its clinical use as a psychoactive agent. Subcell Biochem 2006;39:293-314.

115 Watson DG, Lenox RH: Chronic lithiuminduced down-regulation of MARCKS in immortalized hippocampal cells: potentiation by muscarinic receptor activation. J Neurochem 1996;67:767-777.

116 Manji HK, Lenox RH: Ziskind-Somerfeld Research Award. Protein kinase C signaling in the brain: molecular transduction of mood stabilization in the treatment of manic-depressive illness. Biol Psychiatry 1999; 46:1328-1351.

117 Watterson JM, Watson DG, Meyer EM, Lenox RH: A role for protein kinase $\mathrm{C}$ and its substrates in the action of valproic acid in the brain: implications for neural plasticity. Brain Res 2002;934:69-80.
118 Rizo J, Sudhof TC: The membrane fusion enigma: SNAREs, Sec1/Munc18 proteins, and their accomplices - guilty as charged? Annu Rev Cell Dev Biol 2012;28:279-308.

119 Shimazaki Y, Nishiki T, Omori A, Sekiguchi M, Kamata Y, Kozaki S, Takahashi M: Phosphorylation of 25-kDa synaptosome-associated protein. Possible involvement in protein kinase C-mediated regulation of neurotransmitter release. J Biol Chem 1996;271: 14548-14553.

120 Yamamori S, Sugaya D, Iida Y, Kokubo H, Itakura M, Suzuki E, Kataoka M, Miyaoka H, Takahashi M: Stress-induced phosphorylation of SNAP-25. Neurosci Lett 2014;561: 182-187.

121 Shoji-Kasai Y, Itakura M, Kataoka M, Yamamori S, Takahashi M: Protein kinase C-mediated translocation of secretory vesicles to plasma membrane and enhancement of neurotransmitter release from PC12 cells. Eur J Neurosci 2002;15:1390-1394.

122 Anand A, Verhoeff P, Seneca N, Zoghbi SS, Seibyl JP, Charney DS, Innis RB: Brain SPECT imaging of amphetamine-induced dopamine release in euthymic bipolar disorder patients. Am J Psychiatry 2000;157: 1108-1114.

123 Gigante AD, Young LT, Yatham LN, Andreazza AC, Nery FG, Grinberg LT, Heinsen H, Lafer B: Morphometric post-mortem studies in bipolar disorder: possible association with oxidative stress and apoptosis. Int J Neuropsychopharmacol 2011;14:10751089.

124 Gigante AD, Bond DJ, Lafer B, Lam RW, Young LT, Yatham LN: Brain glutamate levels measured by magnetic resonance spectroscopy in patients with bipolar disorder: a meta-analysis. Bipolar Disord 2012;14:478487.

125 Morris G, Walder K, McGee SL, Dean OM, Tye SJ, Maes M, Berk M: A model of the mitochondrial basis of bipolar disorder. Neurosci Biobehav Rev 2017;74:1-20.

126 Andreazza AC, Kauer-Sant'anna M, Frey BN, Bond DJ, Kapczinski F, Young LT, Yatham LN: Oxidative stress markers in bipolar disorder: a meta-analysis. J Affect Disord 2008;111:135-144.

127 Russo GL, Russo M, Spagnuolo C, Tedesco I, Bilotto S, Iannitti R, Palumbo R: Quercetin: a pleiotropic kinase inhibitor against cancer. Cancer Treat Res 2014;159:185-205.

128 Ferkey DM, Kimelman D: GSK-3: new thoughts on an old enzyme. Dev Biol 2000; 225:471-479.

129 O'Brien WT, Klein PS: Validating GSK3 as an in vivo target of lithium action. Biochem Soc Transact 2009;37:1133-1138.

130 Chen G, Huang LD, Jiang YM, Manji HK: The mood-stabilizing agent valproate inhibits the activity of glycogen synthase kinase-3. J Neurochem 1999;72:1327-1330.

Saxena/Scaini/Bavaresco/Leite/ Valvassoria/Carvalho/Quevedo 
131 Stambolic V, Ruel L, Woodgett JR: Lithium inhibits glycogen synthase kinase- 3 activity and mimics wingless signalling in intact cells. Curr Biol 1996;6:1664-1668.

132 Kirshenboim N, Plotkin B, Shlomo SB, Kaidanovich-Beilin $\mathrm{O}$, Eldar-Finkelman $\mathrm{H}$ : Lithium-mediated phosphorylation of glycogen synthase kinase-3beta involves PI3 kinase-dependent activation of protein kinase C-alpha. J Mol Neurosci 2004;24:237-245.

133 Yu T, Lin W: Small-molecule GSK-3 inhibitor rescued apoptosis and neurodegeneration in anesthetics-injured dorsal root ganglion neurons. Biomed Pharmacother 2016; 84:395-402.

134 Gould TD, Picchini AM, Einat H, Manji HK Targeting glycogen synthase kinase- 3 in the CNS: implications for the development of new treatments for mood disorders. Curr Drug Targets 2006; 7:1399-1409.

135 Havekes R, Meerlo P, Abel T: Animal studies on the role of sleep in memory: from behavioral performance to molecular mechanisms. Curr Topics Behav Neurosci 2015;25: 183-206.

136 Gould TD, Manji HK: Signaling networks in the pathophysiology and treatment of mood disorders. J Psychosom Res 2002;53:687697.

137 Mitchell PB, Manji HK, Chen G, Jolkovsky L, Smith-Jackson E, Denicoff K, Schmidt M, Potter WZ: High levels of Gs alpha in platelets of euthymic patients with bipolar affective disorder. Am J Psychiatry 1997;154: 218-223.

138 Perez J, Tardito D, Mori S, Racagni G, Smeraldi E, Zanardi R: Altered Rap1 endogenous phosphorylation and levels in platelets from patients with bipolar disorder. J Psychiatr Res 2000;34:99-104.

139 Karege F, Schwald M, Papadimitriou P, Lachausse C, Cisse M: The cAMP-dependent protein kinase $\mathrm{A}$ and brain-derived neurotrophic factor expression in lymphoblast cells of bipolar affective disorder. J Affect Disord 2004;79:187-192.

140 Kerner B: Genetics of bipolar disorder. Appl Clin Genet 2014;7:33-42.

141 Carroll LS, Williams NM, Moskvina V, Russell E, Norton N, Williams HJ, Peirce T, Georgieva L, Dwyer S, Grozeva D, Greene E, Farmer A, McGuffin P, Morris DW, Corvin A, Gill M, Rujescu D, Sham P, Holmans P, Jones I, Kirov G, Craddock N, O’Donovan MC, Owen MJ: Evidence for rare and common genetic risk variants for schizophrenia at protein kinase C, alpha. Mol Psychiatry 2010;15:1101-1111.

142 Kandaswamy R, McQuillin A, Curtis D, Gurling H: Tests of linkage and allelic association between markers in the $1 \mathrm{p} 36$ PRKCZ (protein kinase $\mathrm{C}$ zeta) gene region and bipolar affective disorder. Am J Med Genet B Neuropsychiatr Genet 2012;159B:201-209.

143 Kerner B: Toward a deeper understanding of the genetics of bipolar disorder. Front Psychiatry 2015;6:105.
144 McClung CA, Nestler EJ: Neuroplasticity mediated by altered gene expression. Neuropsychopharmacology 2008;33:3-17.

145 Saxena A, Little JT, Nedungadi TP, Cunningham JT: Angiotensin II type 1a receptors in subfornical organ contribute towards chronic intermittent hypoxia-associated sustained increase in mean arterial pressure. Am J Physiol Heart Circ Physiol 2015; 308:H435-H446.

146 Chen G, Yuan PX, Jiang YM, Huang LD, Manji HK: Valproate robustly enhances AP-1 mediated gene expression. Brain Res Mol Brain Res 1999;64:52-58.

147 Ozaki N, Chuang DM: Lithium increases transcription factor binding to AP-1 and cyclic AMP-responsive element in cultured neurons and rat brain. J Neurochem 1997; 69:2336-2344.

148 Yuan PX, Chen G, Huang LD, Manji HK: Lithium stimulates gene expression through the AP-1 transcription factor pathway. Brain Res Mol Brain Res 1998;58:225-230.

149 Brunello N, Tascedda F: Cellular mechanisms and second messengers: relevance to the psychopharmacology of bipolar disorders. Int J Neuropsychopharmacol 2003;6: 181-189.

150 Zeng Z, Wang T, Li T, Li Y, Chen P, Zhao Q, Liu J, Li J, Feng G, He L, Shi Y: Common SNPs and haplotypes in DGKH are associated with bipolar disorder and schizophrenia in the Chinese Han population. Mol Psychiatry 2011;16:473-475.

151 Baum AE, Akula N, Cabanero M, Cardona I, Corona W, Klemens B, Schulze TG, Cichon S, Rietschel M, Nothen MM, Georgi A, Schumacher J, Schwarz M, Abou Jamra R, Hofels S, Propping P, Satagopan J, DeteraWadleigh SD, Hardy J, McMahon FJ: A genome-wide association study implicates diacylglycerol kinase eta (DGKH) and several other genes in the etiology of bipolar disorder. Mol Psychiatry 2008;13:197-207.

152 Kittel-Schneider S, Wobrock T, Scherk H, Schneider-Axmann T, Trost S, Zilles D, Wolf C, Schmitt A, Malchow B, Hasan A, Backens M, Reith W, Falkai P, Gruber O, Reif A: Influence of DGKH variants on amygdala volume in patients with bipolar affective disorder and schizophrenia. Eur Arch Psychiatry Clin Neurosci 2015;265: 127-136.

153 Merida I, Avila-Flores A, Merino E: Diacylglycerol kinases: at the hub of cell signalling. Biochem J 2008;409:1-18.

154 Schwarz E, Prabakaran S, Whitfield P, Major $\mathrm{H}$, Leweke FM, Koethe D, McKenna P, Bahn S: High throughput lipidomic profiling of schizophrenia and bipolar disorder brain tissue reveals alterations of free fatty acids, phosphatidylcholines, and ceramides. J Proteome Res 2008;7:4266-4277.
155 Nigam S, Muller S: 5-Hydroperoxyeicosatetraenoic acid (5-HPETE) enhances the synthesis of 1-O-alkyl-2-sn-acetyl-glycero-3-phosphocholine (PAF) in fMet-LeuPhe-stimulated HL-60 cells: key role of diacylglycerol (DAG) in activation of protein kinase C (PKC). Free Radic Res Commun 1989;7:171-178

156 Mellor H, Parker PJ: The extended protein kinase C superfamily. Biochem J 1998; 332(Pt 2):281-292.

157 Sakane F, Kanoh H: Molecules in focus: diacylglycerol kinase. Int J Biochem Cell Biol 1997;29:1139-1143.

158 Rittiner JE, Brings VE, Zylka MJ: Overexpression of diacylglycerol kinase eta enhances Galphaq-coupled G protein-coupled receptor signaling. Mol Pharmacol 2014;85: 800-810.

159 Machado-Vieira R, Manji HK, Zarate CA Jr: Potential novel therapeutics for bipolar disorders. Curr Topics Behav Neurosci 2011;5: 303-329.

160 Isozaki T, Komenoi S, Lu Q, Usuki T, Tomokata S, Matsutomo D, Sakai H, Bando K, Kiyonari $\mathrm{H}$, Sakane F: Deficiency of diacylglycerol kinase eta induces lithium-sensitive mania-like behavior. J Neurochem 2016;138: 448-456.

161 Moya PR, Murphy DL, McMahon FJ, Wendland JR: Increased gene expression of diacylglycerol kinase eta in bipolar disorder. Int J Neuropsychopharmacol 2010;13:11271128.

162 Rodriguez de Turco EB, Tang W, Topham MK, Sakane F, Marcheselli VL, Chen C, Taketomi A, Prescott SM, Bazan NG: Diacylglycerol kinase epsilon regulates seizure susceptibility and long-term potentiation through arachidonoyl-inositol lipid signaling. Proc Natl Acad Sci USA 2001;98:47404745.

163 Kittel-Schneider S, Lorenz C, Auer J, Weissflog L, Reif A: DGKH genetic risk variant influences gene expression in bipolar affective disorder. J Affect Disord 2016;198:148-157.

164 Wang L, Li H, Zhang Y, Santella RM, Weinstein IB: HINT1 inhibits beta-catenin/TCF4, USF2 and NFkappaB activity in human hepatoma cells. Int J Cancer 2009;124:15261534.

165 Elashoff M, Higgs BW, Yolken RH, Knable MB, Weis S, Webster MJ, Barci BM, Torrey EF: Meta-analysis of 12 genomic studies in bipolar disorder. J Mol Neurosci 2007;31: 221-243.

166 Barbier E, Zapata A, Oh E, Liu Q, Zhu F, Undie A, Shippenberg T, Wang JB: Supersensitivity to amphetamine in protein kinase-C interacting protein/HINT1 knockout mice. Neuropsychopharmacology 2007;32:17741782.

167 Barbier E, Wang JB: Anti-depressant and anxiolytic like behaviors in PKCI/HINT1 knockout mice associated with elevated plasma corticosterone level. BMC Neurosci 2009; 10:132. 
168 Varadarajulu J, Lebar M, Krishnamoorthy G, Habelt S, Lu J, Bernard Weinstein I, Li H, Holsboer F, Turck CW, Touma C: Increased anxiety-related behaviour in Hint1 knockout mice. Behav Brain Res 2011;220:305311.

169 Simon GE, Bauer MS, Ludman EJ, Operskalski BH, Unutzer J: Mood symptoms, functional impairment, and disability in people with bipolar disorder: specific effects of mania and depression. J Clin Psychiatry 2007; 68:1237-1245.

170 Perlis RH, Huang J, Purcell S, Fava M, et al: Genome-wide association study of suicide attempts in mood disorder patients. Am J Psychiatry 2010;167:1499-1507.

171 Pandey GN, Dwivedi Y, SridharaRao J, Ren X, Janicak PG, Sharma R: Protein kinase C and phospholipase $\mathrm{C}$ activity and expression of their specific isozymes is decreased and expression of MARCKS is increased in platelets of bipolar but not in unipolar patients. Neuropsychopharmacology 2002;26: 216-228.
172 Le-Niculescu H, Levey DF, Ayalew M, Palmer L, Gavrin LM, Jain N, Winiger E, Bhosrekar S, Shankar G, Radel M, Bellanger E, Duckworth H, Olesek K, Vergo J, Schweitzer R, Yard M, Ballew A, Shekhar A, Sandusky GE, Schork NJ, Kurian SM, Salomon DR, Niculescu AB 3rd: Discovery and validation of blood biomarkers for suicidality. Mol Psychiatry 2013;18:1249-1264.

173 Data-Franco J, Singh A, Popovic D, Ashton M, Berk M, Vieta E, Figueira ML, Dean OM: Beyond the therapeutic shackles of the monoamines: new mechanisms in bipolar disorder biology. Prog Neuropsychopharmacol Biol Psychiatry 2017;72:73-86.
174 Hains $\mathrm{AB}, \mathrm{Vu} \mathrm{MA}$, Maciejewski PK, van Dyck $\mathrm{CH}$, Gottron M, Arnsten AF: Inhibition of protein kinase $\mathrm{C}$ signaling protects prefrontal cortex dendritic spines and cognition from the effects of chronic stress. Proc Natl Acad Sci USA 2009;106:17957-17962.

175 Hahn CG, Umapathy, Wang HY, Koneru R, Levinson DF, Friedman E: Lithium and valproic acid treatments reduce $\mathrm{PKC}$ activation and receptor-G protein coupling in platelets of bipolar manic patients. J Psychiatr Res 2005;39:355-363.

176 Akimoto T, Kusumi I, Suzuki K, Koyama T: Effects of calmodulin and protein kinase $\mathrm{C}$ modulators on transient $\mathrm{Ca}^{2+}$ increase and capacitative $\mathrm{Ca}^{2+}$ entry in human platelets: relevant to pathophysiology of bipolar disorder. Prog Neuropsychopharmacol Biol Psychiatry 2007;31:136-141.

177 Pandey GN, Ren X, Dwivedi Y, Pavuluri $M N$ : Decreased protein kinase C (PKC) in platelets of pediatric bipolar patients: effect of treatment with mood stabilizing drugs J Psychiatr Res 2008;42:106-116. 